
Environmental Radioactivity, 151 (1). 114-125. 10.1016/j.jenvrad.2015.09.019

(C) 2015 Elsevier Ltd

This manuscript version is made available under the CC-BY-NC-ND 4.0 license http://creativecommons.org/licenses/by-nc-nd/4.0/

(c) EY-NC-ND

This version available http://nora.nerc.ac.uk/511988/

NERC has developed NORA to enable users to access research outputs wholly or partially funded by NERC. Copyright and other rights for material on this site are retained by the rights owners. Users should read the terms and conditions of use of this material at http://nora.nerc.ac.uk/policies.html\#access

NOTICE: this is the author's version of a work that was accepted for publication in Journal of Environmental Radioactivity. Changes resulting from the publishing process, such as peer review, editing, corrections, structural formatting, and other quality control mechanisms may not be reflected in this document. Changes may have been made to this work since it was submitted for publication. A definitive version was subsequently published in Journal of Environmental Radioactivity, 151 (1). 114-125. 10.1016/.j.jenvrad.2015.09.019

www.elsevier.com/

Contact CEH NORA team at noraceh@ceh.ac.uk

The NERC and CEH trademarks and logos ('the Trademarks') are registered trademarks of NERC in the UK and other countries, and may not be used without the prior written consent of the Trademark owner. 


\section{Should we ignore U-235 series contribution to dose?}

Karine Beaugelin-Seiller ${ }^{\mathrm{a}}$, Richard Goulet ${ }^{\mathrm{b}}$, Steve Mihok $^{\mathrm{b}}$, Nicholas A. Beresford ${ }^{\mathrm{c}}$ a Institut de Radioprotection et de Sûreté Nucléaire (IRSN), PRP-ENV, SERIS, LM2E, Cadarache, France b Canadian Nuclear Safety Commission, P.O. Box 1046, Station B, 280 Slater Street, Ottawa, ON K1P 5S9, Canada

c NERC Centre for Ecology \& Hydrology, CEH-Lancaster, Lancaster Environment Centre, Library Avenue, Bailrigg, Lancaster LA1 4AP, UK

* corresponding author:

Karine Beaugelin-Seiller IRSN/PRP-ENV/SERIS/LM2E

Centre of Cadarache bdg 159

BP3

13115 SAINT PAUL LES DURANCE

France

karine.beaugelin@irsn.fr, tel +33442199416

fax +3342199143 
Should we ignore U-235 series contribution to dose?

\section{Highligths:}

- Realistic ecological risk assessment infers a complete inventory of radionuclides

- U-235 family may not be minor when assessing total dose rates experienced by biota

- There is a need to investigate the real state of equilibrium decay of $U$ chains

- $\quad$ There is a need to improve the capacity to measure all elements of the $\mathrm{U}$ decay chains 
Abstract. Environmental Risk Assessment (ERA) methodology for radioactive substances is an important regulatory tool for assessing the safety of licensed nuclear facilities for wildlife, and the environment as a whole. ERAs are therefore expected to be both fit for purpose and conservative. When uranium isotopes are assessed, there are many radioactive decay products which could be considered. However, risk assessors usually assume ${ }^{235} \mathrm{U}$ and its daughters contribute negligibly to radiological dose. The validity of this assumption has not been tested: what might the ${ }^{235} \mathrm{U}$ family contribution be and how does the estimate depend on the assumptions applied? In this paper we address this question by considering aquatic wildlife in Canadian lakes exposed to historic uranium mining practices. A full theoretical approach was used, in parallel to a more realistic assessment based on measurements of several elements of the $U$ decay chains. The ${ }^{235} U$ family contribution varied between about $4 \%$ to $75 \%$ of the total dose rate depending on the assumptions of the equilibrium state of the decay chains. Hence, ignoring the ${ }^{235} \mathrm{U}$ series will not result in conservative dose assessments for wildlife. These arguments provide a strong case for more in situ measurements of the important members of the ${ }^{235} \mathrm{U}$ chain and for its consideration in dose assessments

\section{Introduction}

The mining and milling of uranium ore bodies result in releases of uranium and radioactive decay products to aquatic ecosystems. Although modern effluent controls are efficient, operational releases result in the accumulation of contaminants in near field sediments. Predicting ecological risks in these near field aquatic systems is complicated by the many radioactive daughters of the uranium decay series, and the partitioning of contaminants between water and sediments. Predictive ecological risk assessments are therefore conservative to compensate for data gaps and uncertainties to ensure the protection of the receiving aquatic environment.

It is our current understanding that ecological risks appear to be higher for chemical toxicity than radiological toxicity for natural uranium based on certain assumptions about attainment of secular 
equilibrium and partitioning of daughters (Mathews et al., 2009). It therefore remains important to refine radiological risk assessment methods to fully characterize the hazardous nature of uranium in a fully integrated manner for all associated contaminants and pathways.

Both wildlife and human radioprotection systems share the concept of additive risk assuming that effects of exposure to radioactivity are linked to the dose, or energy, received by organisms regardless of the radionuclide. In theory such a concept relies upon a complete inventory of radionuclides to which receptors are exposed so that total radiological risk is not underestimated.

Three radioisotopes of uranium are naturally found in the environment: ${ }^{234} \mathrm{U},{ }^{235} \mathrm{U}$ and ${ }^{238} \mathrm{U} .{ }^{238} \mathrm{U}$ and ${ }^{234} \mathrm{U}$ each represent $49 \%$ to the specific activity of natural uranium (Cossonnet et al., 2001) and are generally considered in dose assessments. ${ }^{238} \mathrm{U}$ is the precursor of a radioactive decay chain, producing a long series of radioactive daughters including isotopes such as ${ }^{234} \mathrm{U},{ }^{230} \mathrm{Th},{ }^{226} \mathrm{Ra},{ }^{210} \mathrm{~Pb}$, and ${ }^{210} \mathrm{Po}$ (Fig. 1), that can contribute significantly to dose. As a result, ${ }^{238} \mathrm{U}$ and daughters radionuclides ${ }^{230} \mathrm{Th}$, ${ }^{226} \mathrm{Ra},{ }^{210} \mathrm{Po}$ and ${ }^{210} \mathrm{~Pb}$ are routinely monitored in the environment, for instance, downstream of decommissioned and operating $\mathrm{U}$ mines and mills.

In contrast, Uranium-235 contributes only $2 \%$ to the specific activity of natural uranium (Cossonnet et al., 2001), and is generally not explicitly considered in dose assessments, being either ignored or at best estimated from ${ }^{238} \mathrm{U}$ data (the isotopic ratio ${ }^{235} \mathrm{U} /{ }^{238} \mathrm{U}$ is approximately 0.04 ). ${ }^{235} \mathrm{U}$ is also a precursor of a radioactive decay chain, with seven radioactive daughters that may contribute significantly to dose $\left({ }^{231} \mathrm{~Pa},{ }^{227} \mathrm{Th},{ }^{223} \mathrm{Ra},{ }^{219} \mathrm{Rn},{ }^{215} \mathrm{Po}\right.$ and ${ }^{211} \mathrm{Bi}$ (Table A1)). However, there are no measured data for components of the ${ }^{235} \mathrm{U}$ decay series in environmental samples, because their analysis methods are complex and costly (Sheppard and Herod, 2012). Instead, radio-ecologists can only estimate the activity of daughter radionuclides in environmental media and in non-human biota by assuming that radionuclide daughters are in a given equilibrium with the parent ${ }^{235} \mathrm{U}$ isotope (which concentration is usually assumed and not measured). 
This paper addresses if ignoring ${ }^{235} \mathrm{U}$ series radionuclides is justified using an example of a freshwater environment at a historic uranium mining area in Canada. These data have also been used as part of a scenario for an International Atomic Energy Agency modelling exercise (IAEA in-press).

\section{Overview of Canadian U mines scenario}

The scenario was based upon data collected in the vicinity of historic mining and milling sites in northern Saskatchewan (Canada). Here we present an overview of the elements relevant to the present study. Participants were asked to estimate the weighted dose rates received by benthic and pelagic fish, and aquatic invertebrates. They were provided with radionuclide measurements $\left({ }^{238} \mathrm{U},{ }^{230} \mathrm{Th}\right.$, $\left.{ }^{226} \mathrm{Ra},{ }^{210} \mathrm{Po},{ }^{210} \mathrm{~Pb}\right)$ in water, sediments and organisms, the availability of data differed between samples types and the sites included in the exercise. There were large differences between some model results, from estimated activity concentrations to calculated dose rates. One major difference between approaches was the way in which $\mathrm{U}$ isotopes and their decay products were taken into account. At one extreme, assessments only considered the five measured radionuclides for which information was provided, whereas others considered an exhaustive approach that included all U-238 series radionuclides (IAEA in-press). Virtually all of the participants ignored the contribution of the U-235 series.

This paper focuses on the validity of this latter assumption. Firstly the ${ }^{235} \mathrm{U}$ family contribution to dose rates experienced by aquatic organisms was assessed under the hypothesis of steady state equilibrium between all components of the decay chains, as often assumed in the absence of any measurement data. This result was then compared to a more realistic approach taking into account the available information from one of the Canadian sites included in the scenario.

\section{Method}

\subsection{General principles}

Radionuclides having the same mode of action are assumed to have additive effects. To inform about radiological risks, an environmental risk assessment for uranium should therefore consider all daughter products associated with the element and which may contribute significantly to dose. Here 
we will consider only those uranium decay products that exhibit a branching ratio higher than 0.9 (Fig. 1 and 2). Only some of the decay products are measurable via classical nuclear metrology methods: the six first members of the chain are relatively easily quantified by spectrometry $(\gamma$ or $\alpha)$, if their activity is sufficiently high. For the others, it is only possible to make assumptions regarding the equilibrium state of the decay chain to estimate their activities.

The basic equation to assess the total dose rate $D R(I, O)$ received by an organism $O$ exposed to a radionuclide $I$ is the following (Beresford et al., 2007):

$$
D R(I, O)=D C C_{\mathrm{int}}(I, O) \cdot C R(I, O) \cdot C_{\text {media }}(I)+D C C_{e x t}(I, O) \cdot C_{\text {media }}(I)
$$

where $D C C_{i n t}$ and $D C C_{e x t}$ are the dose conversion coefficients relating organism activity and media $\left(C_{\text {media }}\right)$ activity concentrations to internal and external dose rates respectively $\left(\mu \mathrm{Gy} \mathrm{h} / \mathrm{Bq} \mathrm{kg}^{-1}\right)$. In the case of aquatic systems $C_{\text {media }}$ may be water or sediment activity concentrations for pelagic or benthic organisms respectively; for organisms at the sediment-water interface $D C C_{e x t}(I, O) \cdot C_{\text {media }}(I)$ is estimated for both media types usually assuming 50\% exposure to sediments and $50 \%$ to water.

There are two possibilities to take into account daughter products for more realism in an assessment. The first approach consists of considering the decay chain of interest in an integrated manner through the use of a 'family DCC' that includes all or some of the daughters, depending on their half-lives. This assumes secular equilibrium between the parent radionuclide and the decay products both in the external media and inside organisms. As an example of this first solution, dosimetric approach used to derive DCC values in the ERICA Tool (Brown et al., 2008) includes daughter products with half-lives up to 10 days (e.g. the DCCs for ${ }^{234} \mathrm{Th}$ include ${ }^{234 \mathrm{~m}} \mathrm{~Pa}$ ) (Ulanovsky et al., 2008). In contrast, the RESRAD-BIOTA code (ISCORS, 2004) includes daughters with half-lives lower than a userselectable cut-off of $180 \mathrm{~d}$ or 100 years. These methods have one major limitation, they suppose that daughter products and their parent are subject to the same transfer processes, i.e. the same transfer parameters are in-effect applied to all the radionuclides included in the family DCC. This is a simplifying assumption which has not been tested to our knowledge; moreover there is no clear scientific justification rather it has been adopted for pragmatic reasons. Without evidence there is no 
way to know if this approach is conservative. In addition, users have to take care to not calculate doses for daughter products already integrated in the DCCs, an easy conceptual error leading to an overestimation of the radiological risk (Vives i Batlle et al., 2007).

The work described here uses individual DCCs for each radionuclide of the U-decay series. The DCCs (Supplementary material, Table A1) were calculated using the EDEN software (Beaugelin-Seiller et al., 2006) assuming geometry details as provided in the Canadian U mine scenario (IAEA in-press) for two organisms living in contrasting habitats, a pelagic fish (pike, Esox lucius) and a benthic invertebrate, a Pisidium species mollusc (Table 1). A pike was assumed to spend $75 \%$ of its time in water (in the middle of a $2 \mathrm{~m}$ water column) and $25 \%$ at the sediment interface (on a $0.5 \mathrm{~m}$ sediment layer under the $2 \mathrm{~m}$ water column), whereas a mollusc was assumed to spend all its time at the watersediment interface. A supplementary exposure scenario was also considered, in which the mollusc is located in the middle of the sediment layer. In addition to ${ }^{238} \mathrm{U}$ and daughters, including the ${ }^{235} \mathrm{U}$ series in an Ecological Risk Assessment (ERA) leads to consideration of two additional elements, Ac and Tl, and 11 additional radioisotopes (Fig. 2). DCCs were weighted according to the relative biological effectiveness of the different radiations as suggested by Pröhl et al. (2003): 10 for $\alpha, 3$ for $\beta$ and 1 for $\gamma$ emissions.

Table 1: Assumed organism characteristics

Anatomical parameters (size in $\mathrm{cm} /$ mass in $\mathrm{kg}$ )

\begin{tabular}{cccccc}
\hline Species & Length & Height & Width & Mass & References \\
\hline Pike & 50 & 15 & 10 & 1200 & $\begin{array}{c}\text { Golder Associates, 2006, 2008 } \\
\text { (Esox } \\
\text { lucius })\end{array}$ \\
\hline Pisidium sp. & 2.5 & 1.5 & 1 & 1.6 & $\begin{array}{c}\text { Kilgour and Mackie, 1991 } \\
\text { Funk and Reckendorfer, 2008 }\end{array}$ \\
\hline
\end{tabular}

\subsection{Theoretical approach}

123 Assumptions of equilibrium within decay chains were made for both water and sediment. Table 2 presents relative activity concentrations of the daughter products assuming $1 \mathrm{~Bq} \mathrm{~L}^{-1}$ or Bq kg-1 (dry mass, $\mathrm{dm}){ }^{238} \mathrm{U}$ in water or sediment respectively estimated under the hypothesis of radioactive decay 
equilibrium. Outgassing of radon with a distribution coefficient of $0.4 \mathrm{~m}^{3} \mathrm{~m}^{-3}$ (Sabroux, 1998) and a natural isotopic ratio between ${ }^{235} \mathrm{U}$ and ${ }^{238} \mathrm{U}$ of 0.047 (Cossonnet et al., 2001) were assumed. The ${ }^{235} \mathrm{U}:{ }^{238} \mathrm{U}$ ratio has some natural variability, depending on the matrix. Shepppard \& Herod (2012) cited an average ratio of 0.028 and 0.035 respectively for water and soil from the literature. They also acquired new data for water, from which they estimated a ratio of 0.048 . The exact value of this ratio

131 is not critical to our study's objectives, as while the variability in environmental samples varies from

132 less than $0.03 \%$ (Cowan and Adler, 1976; Richter et al., 1999; Bopp et al., 2009) to 0.3\% (Stirling et 133 al., 2007; Weyer et al., 2008; Sun et al., 2008; Del Papa et al., 2010), the ${ }^{235} \mathrm{U}$ activity concentration is 134 low relative to ${ }^{238} \mathrm{U}$.

135 Table 2: Relative activity concentrations used for the theoretical approach

\begin{tabular}{lll}
\hline Radionuclide & $\begin{array}{l}\text { Concentration } \\
\left(\mathrm{Bq} \mathrm{L}^{-1} \text { or } \mathrm{Bq} \mathrm{kg}^{-1}\right)\end{array}$ & Hypothesis \\
\hline${ }^{238} \mathrm{U}$ & 1 & - \\
\hline${ }^{234 \mathrm{Th}},{ }^{234 \mathrm{~m}} \mathrm{~Pa},{ }^{234} \mathrm{U},{ }^{230 \mathrm{Th}},{ }^{226} \mathrm{Ra}$ & 1 & Radioactive equilibrium with ${ }^{238} \mathrm{U}$ \\
\hline${ }^{222} \mathrm{Rn}$ & 0.4 & Loss by outgassing \\
\hline${ }^{218} \mathrm{Po},{ }^{214} \mathrm{~Pb},{ }^{214} \mathrm{Bi},{ }^{214} \mathrm{Po},{ }^{210} \mathrm{~Pb},{ }^{210} \mathrm{Bi}$, & 0.4 & Radioactive equilibrium with ${ }^{222} \mathrm{Rn}$ \\
${ }^{210} \mathrm{Po}$ & 0.047 & Natural isotopic ratio ${ }^{235} \mathrm{U} /{ }^{238} \mathrm{U}$ \\
\hline${ }^{235} \mathrm{U}$ & 0.047 & Radioactive equilibrium with ${ }^{235} \mathrm{U}$ \\
\hline${ }^{231} \mathrm{Th},{ }^{231} \mathrm{~Pa},{ }^{227} \mathrm{Ac},{ }^{227} \mathrm{Th},{ }^{223} \mathrm{Ra}$ & 0.019 & Loss by outgassing \\
\hline${ }^{219} \mathrm{Rn}$ & 0.019 & Radioactive equilibrium with ${ }^{219} \mathrm{Rn}$ \\
\hline${ }^{215} \mathrm{Po},{ }^{211} \mathrm{~Pb},{ }^{211} \mathrm{Bi},{ }^{207} \mathrm{Tl}$ & & \\
\hline
\end{tabular}

137 When radioactive decay equilibrium was assumed in water, we assessed the sediment activity 138 concentrations under the hypothesis of steady-state transfer as determined by the classical partition 139 coefficient Kd (Table 3, Fig.3 upper graph). When decay equilibrium was assumed in sediment, water 140 concentrations were estimated in an inverse way from sediment concentrations. In either case, 141 organism activity concentrations were then obtained by applying concentration ratios to water activity 142 concentrations (Table 3, Fig.3 lower graph). 
Table 3: Values and origin of transfer parameters

\begin{tabular}{|c|c|c|c|c|c|c|}
\hline \multirow[b]{2}{*}{ Isotope } & \multicolumn{2}{|r|}{$\mathrm{Kd}$} & \multicolumn{2}{|r|}{ CR pike } & \multicolumn{2}{|r|}{ CR Pisidium } \\
\hline & Value & Origin* & Value & Origin & Value & Origin \\
\hline${ }^{238} \mathrm{U}$ & $2.87 \mathrm{E}+02$ & ERICA Tool 2014 & $7.24 \mathrm{E}+01$ & Copplestone et al., 2013 & $5.57 \mathrm{E}+02$ & Copplestone et al., 2013 \\
\hline${ }^{234} \mathrm{Th}$ & $1.96 \mathrm{E}+07$ & ERICA Tool 2014 & $7.13 \mathrm{E}+02$ & Copplestone et al., 2013 & $1.04 \mathrm{E}+04$ & Mollusc Am** \\
\hline${ }^{234 \mathrm{~m}} \mathrm{~Pa}$ & $1.96 \mathrm{E}+07$ & ERICA Tool 2014 & $8.33 \mathrm{E}+02$ & Mollusc Am & $1.04 \mathrm{E}+04$ & Mollusc Am \\
\hline${ }^{234} \mathrm{U}$ & $2.87 \mathrm{E}+02$ & ERICA Tool 2014 & $7.24 \mathrm{E}+01$ & Copplestone et al., 2013 & $5.57 \mathrm{E}+02$ & Copplestone et al., 2013 \\
\hline${ }^{230} \mathrm{Th}$ & $1.96 \mathrm{E}+07$ & ERICA Tool 2014 & $7.13 \mathrm{E}+02$ & Copplestone et al., 2013 & $1.04 \mathrm{E}+04$ & Mollusc Am \\
\hline${ }^{226} \mathrm{Ra}$ & $1.40 \mathrm{E}+04$ & ERICA Tool 2014 & $1.81 \mathrm{E}+02$ & Copplestone et al., 2013 & $2.43 \mathrm{E}+04$ & Copplestone et al., 2013 \\
\hline${ }^{222} \mathrm{Rn}$ & $8.00 \mathrm{E}-01$ & Brown et al.,2004 & $8.00 \mathrm{E}-01$ & Brown et al., 2004 & $8.00 \mathrm{E}-01$ & Brown et al.,2004 \\
\hline${ }^{218} \mathrm{Po}$ & $1.78 \mathrm{E}+04$ & ERICA Tool 2014 & $2.03 \mathrm{E}+03$ & Copplestone et al., 2013 & $1.24 \mathrm{E}+05$ & Copplestone et al., 2013 \\
\hline${ }^{214} \mathrm{~Pb}$ & $1.78 \mathrm{E}+04$ & ERICA Tool 2014 & $1.23 \mathrm{E}+03$ & Copplestone et al., 2013 & $5.79 \mathrm{E}+03$ & Copplestone et al., 2013 \\
\hline${ }^{214} \mathrm{Bi}$ & $1.20 \mathrm{E}+03$ & Wang et al., $2001 ; 2003$ & $1.50 \mathrm{E}+01$ & Staven et al., 2003 & $1.00 \mathrm{E}+05$ & Staven et al.,2003 \\
\hline${ }^{214} \mathrm{Po}$ & $1.78 \mathrm{E}+04$ & ERICA Tool 2014 & $2.03 \mathrm{E}+03$ & Copplestone et al., 2013 & $1.24 \mathrm{E}+05$ & Copplestone et al., 2013 \\
\hline${ }^{210} \mathrm{~Pb}$ & $1.78 \mathrm{E}+04$ & ERICA Tool 2014 & $1.23 \mathrm{E}+03$ & Copplestone et al., 2013 & $5.79 \mathrm{E}+03$ & Copplestone et al., 2013 \\
\hline${ }^{210} \mathrm{Bi}$ & $1.20 \mathrm{E}+03$ & Wang et al., $2001 ; 2003$ & $1.50 \mathrm{E}+01$ & Staven et al., 2003 & $1.00 \mathrm{E}+05$ & Staven et al.,2003 \\
\hline${ }^{210} \mathrm{Po}$ & $1.78 \mathrm{E}+04$ & ERICA Tool 2014 & $2.03 \mathrm{E}+03$ & Copplestone et al., 2013 & $1.24 \mathrm{E}+05$ & Copplestone et al., 2013 \\
\hline${ }^{235} \mathrm{U}$ & $2.87 \mathrm{E}+02$ & ERICA Tool 2014 & $7.24 \mathrm{E}+01$ & Copplestone et al., 2013 & $5.57 \mathrm{E}+02$ & Copplestone et al., 2013 \\
\hline${ }^{231} \mathrm{Th}$ & $1.96 \mathrm{E}+07$ & ERICA Tool 2014 & $7.13 \mathrm{E}+02$ & Copplestone et al., 2013 & $1.04 \mathrm{E}+04$ & Mollusc Am \\
\hline${ }^{231} \mathrm{~Pa}$ & $1.96 \mathrm{E}+07$ & ERICA Tool 2014 & $8.33 \mathrm{E}+02$ & Mollusc Am & $1.04 \mathrm{E}+04$ & Mollusc Am \\
\hline${ }^{227} \mathrm{Ac}$ & $2.00 \mathrm{E}+06$ & IAEA 2001 & $2.50 \mathrm{E}+01$ & Staven et al.,2003 & $1.00 \mathrm{E}+03$ & Staven et al.,2003 \\
\hline${ }^{227} \mathrm{Th}$ & $1.96 \mathrm{E}+07$ & ERICA Tool 2014 & $7.13 \mathrm{E}+02$ & Copplestone et al., 2013 & $1.04 \mathrm{E}+04$ & Mollusc Am \\
\hline${ }^{223} \mathrm{Ra}$ & $1.40 \mathrm{E}+04$ & ERICA Tool 2014 & $1.81 \mathrm{E}+02$ & Copplestone et al., 2013 & $2.43 \mathrm{E}+04$ & Copplestone et al., 2013 \\
\hline${ }^{219} \mathrm{Rn}$ & $8.00 \mathrm{E}-01$ & Brown et al.,2004 & $8.00 \mathrm{E}-01$ & Brown et al.,2004 & $8.00 \mathrm{E}-01$ & Brown et al.,2004 \\
\hline${ }^{215} \mathrm{Po}$ & $1.78 \mathrm{E}+04$ & ERICA Tool 2014 & $2.03 \mathrm{E}+03$ & Copplestone et al., 2013 & $1.24 \mathrm{E}+05$ & Copplestone et al., 2013 \\
\hline${ }^{211} \mathrm{~Pb}$ & $1.78 \mathrm{E}+04$ & ERICA Tool 2014 & $1.23 \mathrm{E}+03$ & Copplestone et al., 2013 & $5.79 \mathrm{E}+03$ & Copplestone et al., 2013 \\
\hline${ }^{211} \mathrm{Bi}$ & $1.20 \mathrm{E}+03$ & Wang et al., $2001 ; 2003$ & $1.50 \mathrm{E}+01$ & Staven et al.,2003 & $1.00 \mathrm{E}+05$ & Staven et al.,2003 \\
\hline${ }^{207} \mathrm{Tl}$ & $2.00 \mathrm{E}-04$ & IAEA 2001 & $1.00 \mathrm{E}+02$ & IAEA 2014 & $5.00 \mathrm{E}+03$ & Staven et al.,2003 \\
\hline
\end{tabular}


Up-to-date values were used, consulting the latest version of different databases (ERICA Tool -

V1.2.0- 2014 (http://www.erica-tool.eu/); Wildlife Transfer Database (Copplestone et al., 2013)). The

CR values for Pisidium are those for a bivalve mollusc when available, and for pike for a pelagic fish. Due to lack of data, some older documents had to be consulted for some values, and finally, some extrapolations were required as indicated in Table 3 (these extrapolations were in accordance with those used in various assessment tools (e.g. Brown et al. 2013)).

\subsection{Realistic approach}

The approach presented above relies on assumptions about decay chain equilibrium, deriving all the information for daughters from the ${ }^{238} \mathrm{U}$ activity concentrations in water or sediment. Comprehensive data for all the decay products have yet to be obtained for environmental samples due to methodological constraints, but some representative data are available for a few key isotopes. This was the case for Keddy Bay of Beaverlodge Lake (one of the sites included in the Canadian U mine scenario (IAEA, in-press)), from which we have selected data for analysis (Table 4). Data gaps were filled following the same extrapolation rules as for the theoretical approach. These measurements were used preferentially to model activity concentrations in media and organisms (and estimate dose rates). In situ transfer parameters were derived when possible, using data obtained at, or close to, Keddy Bay (IAEA, in-press). A Kd value for uranium isotopes was estimated for the site and we determined site specific concentration ratios for uranium, radium and lead for pike (Table 5).

Table 4: Available measurements at Keddy Bay

\begin{tabular}{lcc}
\hline & \multicolumn{2}{c}{ Radionuclide concentration } \\
\hline Radionuclide & water $\left(\mathrm{Bq} \mathrm{L}^{-1}\right)$ & sediment $\left(\mathrm{Bq} \mathrm{kg}^{-1} \mathrm{dm}\right)$ \\
\hline${ }^{238} \mathrm{U}$ & $1.83 \times 10^{0}$ & $1.18 \times 10^{3}$ \\
\hline${ }^{226} \mathrm{Ra}$ & $1.00 \times 10^{-2}$ & n.a. \\
\hline${ }^{210} \mathrm{~Pb}$ & n.a. & $2.53 \times 10^{2}$ \\
\hline
\end{tabular}




\begin{tabular}{ccc}
\hline Isotope & $\mathrm{Kd}$ & $\mathrm{CR}$ pike \\
\hline $\mathrm{U}$ & $6.44 \times 10^{2}$ & $2.70 \times 10^{0}$ \\
$\mathrm{Ra}$ & n.a & $2.62 \times 10^{1}$ \\
$\mathrm{~Pb}$ & n.a & $8.04 \times 10^{1}$ \\
\hline
\end{tabular}

\section{Results}

\subsection{Activity concentrations}

172 In the medium (water or sediment) where decay chains are assumed to be at equilibrium, activity concentrations obtained applying the theoretical approach decrease gradually from ${ }^{238} \mathrm{U}$ to the ${ }^{235} \mathrm{U}$ chain. This logical continuity is not seen when converting water activity concentrations into sediment activity concentrations, or vice-versa, using Kd values. For instance, if we assume decay equilibrium in water then the highest values in sediment are predicted for Th (and $\mathrm{Pa}$ as its $\mathrm{Kd}$ is extrapolated from the value for Th) and Ac, due to their high Kd values (Fig. 3 upper graph). A similar phenomenon occurs when calculating organism activity concentrations, for which the highest values are obtained for Pa in fish, Po in fish and invertebrates, and Bi in invertebrates, due to the high associated CRs (Fig. 3 lower graph). The ranking of radionuclides differs as if it is established from water activity concentration, from sediment activity concentration or from dose rates.

At Keddy Bay, the ${ }^{226} \mathrm{Ra}$ concentration measured in water is actually about one hundred times lower than expected assuming decay equilibrium in water based on the activity of ${ }^{238} \mathrm{U}$. No data were available for ${ }^{235} \mathrm{U}$ and its daughters, and consequently we applied the theoretical approach described above to estimate activity concentrations of this radionuclide. From this we obtained a mixed (measurement plus extrapolation) concentration spectrum in water, considering decay equilibrium, different to the fully theoretical one (Fig.4 upper graph). ${ }^{235} \mathrm{U}$ family activity concentrations are in this case considerably higher than those of ${ }^{226} \mathrm{Ra}$ and its decay products. If decay equilibrium is assumed in sediment and the additional data from Tables 4 and 5 are used, the two approaches give estimates broadly in agreement (Fig.4 lower graph). 
192 Following the theoretical approach, Figure 5 presents the estimated contribution to total dose rate of

193

194

195

196

197

198

199

200

201

203

204

205

206

207

208

209

210

211

212

213

214 pike and Pisidium assuming isotopic equilibrium in water (upper graph) and comparing this with an equilibrium assumption for sediment (lower graph). Assuming radioactive decay equilibrium in water,

Po isotopes are the major contributors to total dose for both organisms considered (70 and $80 \%$ of the total dose rates for fish and Pisidium respectively). This is in part due to the high CR values for Po. These isotopes also contribute significantly to the dose rate assessed for the mollusc when considering isotopic equilibrium in sediment, but to a lesser extent, contributing about $50 \%$ of total dose. This is not the case for fish, for which $80 \%$ of the total dose rate originates from its internal exposure to ${ }^{222} \mathrm{Rn}$, ${ }^{238} \mathrm{U}$ and ${ }^{234} \mathrm{U}$ when sediment isotopic equilibrium is assumed. For these cases, the contribution of the ${ }^{235} \mathrm{U}$ family to total dose rate for Pisidium varies from about $4 \%$ (equilibrium in water) to $12 \%$ (equilibrium in sediment), when the invertebrate is in the sediment or at its surface (Fig. 5). For fish, the percentage increases to about $5 \%$ considering decay chains at equilibrium in water, but is lower $(\sim 4 \%)$ considering decay chains at equilibrium in sediment.

Using the realistic approach, differences in activity concentrations measured or estimated at Keddy Bay propagated through all calculations, from transfer to dosimetry. After the contribution of ${ }^{230} \mathrm{Th}(\sim$ 40\%, Fig. 6 upper graph), the highest dose rates were for the mollusc for decay chains at equilibrium in water due to exposure from ${ }^{215} \mathrm{Po}$ and ${ }^{211} \mathrm{Bi}$, two members of the ${ }^{235} \mathrm{U}$ decay chain. These contributed more than $25 \%$ of the total estimated absorbed dose rate. This resulted mainly from the internal exposure. These three radionuclides have some of the highest CR and internal DCC values, combined with comparatively higher activities of ${ }^{235} \mathrm{U}$ and daughter products in water with regard to the theoretical case. For fish, the highest dose rate is associated with ${ }^{230} \mathrm{Th}(50 \%)$, a decay product of ${ }^{238} \mathrm{U}$, followed by one of the ${ }^{235} \mathrm{U}$ daughter products, ${ }^{227} \mathrm{Th}$ (25\%) (Fig.6). Overall, the whole ${ }^{235} \mathrm{U}$ family contribution is similar for both organisms. The contribution is substantial as it approaches $40 \%$ of the total dose rate. 
Assuming decay equilibrium in sediment (Fig.6 lower graph) results in a dominance of ${ }^{210} \mathrm{Po}$ in the total dose rate $(\sim 63 \%)$ for mollusc though less for fish $(\sim 38 \%)$. For fish, the main contributor is ${ }^{222} \mathrm{Rn}$ ( $45 \%)$. Its dominance in fish results from a high internal dose rate. Radon internal DCCs are among the highest, along those of Po. In contrast to Po, Rn shows a low CR though also a low Kd, leading to a high activity concentration in water.

Although ${ }^{222} \mathrm{Rn}$ is acknowledged to contribute potentially highly to doses for terrestrial organisms, via

222

223 inhalation pathways (Beresford et al., 2012), the importance of its respiration in terms of doses is likely to be less for aquatic animals (Hosseini et al., 2010), exposure from dissolved ${ }^{222} \mathrm{Rn}$ to some organs (e.g. gills and alimentary tract) requires further consideration. Such an argument justifies assessing the impact of ${ }^{222} \mathrm{Rn}$, despite the lack of robustness of the available CR value. In the absence of measured data (Lucas et al., 1979), the CR value used here for all organisms was obtained from Brown et al. (2004). Brown et al. simply assumed that radon in the water in any organism is in equilibrium with radon in the surrounding water. This is a reasonable assumption for a noble gas which is highly soluble/mobile in water-based "media". However, this assumption may be far too conservative for the deposition/retention of radon's short-lived daughters, which are responsible for much of the dose from radon in our simplified theoretical treatment. The retention of any radium decaying in vivo in any tissue other than bone may be only a few percent (ICRP, 1993). Our treatment of radon and its daughters in a transfer factor context is highly uncertain, however, despite the need for data, relevant experimental and environmental information remain sparse. Therefore, due to the paucity of data, we acknowledge that it is difficult to interpret the relative importance of the radon contribution to fish exposure, though here we have made an assessment based upon the limited information available.

The estimated contribution of the ${ }^{235} \mathrm{U}$ family may be as high as $40 \%$ of the total dose rates experienced by aquatic organisms exposed to uranium at Keddy Bay (Fig. 6). This percentage decreases to about 3 to $6 \%$ for both organisms when considering decay equilibrium in sediment rather than in water. Lifestyle of organisms significantly impacts the result. Increasing the time spent in the water column by pike to $100 \%$ decreases the contribution of the ${ }^{235} \mathrm{U}$ family for the fish to about $17 \%$, 
assuming decay equilibrium in water. This effect is not seen when decay equilibrium is considered in sediment.

The greater contribution of ${ }^{235} \mathrm{U}$ series radionuclides compared to the theoretical approach, at least for decay equilibrium considered in water, is the consequence of the lower concentrations of ${ }^{226} \mathrm{Ra}$ in water based upon measurements rather than assumed equilibrium.

\section{Discussion}

\subsection{Estimating dose rates using the theoretical as oppose to a more realistic approach}

The realistic scenario from Keddy Bay identified three dominant radionuclides, ${ }^{230} \mathrm{Th},{ }^{215} \mathrm{Po}$ and ${ }^{211} \mathrm{Bi}$, in the estimates of both mollusc concentrations and total dose rate. Together, they contribute about $70 \%$ of the total dose. Considering equilibrium of their respective decay chains in water and in the absence of any other information, activity concentrations in water of these isotopes were extrapolated directly from the activity of ${ }^{238} \mathrm{U}$ or, for the two members of the ${ }^{235} \mathrm{U}$ decay chain, from the natural isotopic ratio ${ }^{235} \mathrm{U} /{ }^{238} \mathrm{U}$, taking into account radon outgassing. This last assumption led to relatively low concentrations of these radionuclides in water that are counterbalanced by their high default transfer parameters. Moreover, the three radioisotopes have DCC values amongst the highest for internal exposure of the mollusc of all the radionuclides of the two U-isotope decay chains. The total Pisidium dose rate estimated for ${ }^{230} \mathrm{Th},{ }^{215} \mathrm{Po}$ and ${ }^{211} \mathrm{Bi}$ is then dominated by the internal contribution. Calculation was done assuming transfer at equilibrium, applying element CRs without distinction between isotopes. This approach does not account for half-lives that may be very short (e.g. less than a second for ${ }^{215} \mathrm{Po}$, about $2 \mathrm{~m}$ for ${ }^{211} \mathrm{Bi}$ ). Assessing activity concentration of such isotopes in organisms via the equilibrium approach may therefore overestimate activity concentration and hence dose rates.

The large disequilibrium between ${ }^{238} \mathrm{U}$ and ${ }^{226} \mathrm{Ra}$ activity concentrations measured in water increases the contribution of the ${ }^{235} \mathrm{U}$ family to the dose rates received by both organisms. Compared to the assumption of steady state throughout the ${ }^{238} \mathrm{U}$ decay chain applied in the theoretical approach (implying equal concentrations of the two radionuclides), the break in equilibrium at ${ }^{226} \mathrm{Ra}$ decreased its concentration (and all subsequent daughters) by two orders of magnitude compared to ${ }^{238} \mathrm{U}$. 
269 Whereas ${ }^{235} \mathrm{U}$ family concentrations were reasonably derived from the ${ }^{238} \mathrm{U}$ measurement, applying the natural isotopic ratio ${ }^{235} \mathrm{U} /{ }^{238} \mathrm{U}$ to the entire ${ }^{235} \mathrm{U}$ chain (which includes ${ }^{223} \mathrm{Ra}-{ }^{219} \mathrm{Rn}$ ) may not be realistic. This assumption is a potential weak point in the theoretical calculations. This issue needs to be addressed by measuring at least some of the more important members of the ${ }^{235} \mathrm{U}$ chain in sediments, where concentrations are likely high enough to obtain meaningful results. Finally, taking into account the radon degassing for the four last members of the ${ }^{235} \mathrm{U}$ family only decreased their concentrations by about a factor two.

The approach described above was based on the use of individual DCCs for each of the radioisotope of the decay chains. It could be argued that this will limit the number of underlying assumptions regarding decay equilibrium. It has to be noted that to conduct the calculation, other numerous assumptions (e.g. transfer parameters, transfer of decay products etc.) are required that may influence the final result. The extent to which the use of individual DCCs may change the weight of the ${ }^{235} \mathrm{U}$ family contribution to dose rates was tested relative to the use of the alternative approach of family DCCs (or integrated DCCs) by applying the ERICA Tool (Brown et al., 2008). The tool lumps together parents and daughters with half-lives $\leq 10$ days (Ulanovski et al., 2008). The DCC of ${ }^{226} \mathrm{Ra}$ includes DCCs related to ${ }^{222} \mathrm{Rn},{ }^{218} \mathrm{Po},{ }^{214} \mathrm{~Pb},{ }^{214} \mathrm{Bi},{ }^{214} \mathrm{Po}$ and ${ }^{218} \mathrm{At}$ (Fig.1). The same assumption applies to ${ }^{210} \mathrm{~Pb}$ (daughter included: ${ }^{210} \mathrm{Bi}$ ), ${ }^{235} \mathrm{U}$ (daughter included: ${ }^{231} \mathrm{Th}$ ) and ${ }^{223} \mathrm{Ra}$ (daughters included: ${ }^{219} \mathrm{Rn},{ }^{215} \mathrm{Po},{ }^{211} \mathrm{~Pb},{ }^{211} \mathrm{Bi},{ }^{207} \mathrm{Tl}$ ) (Fig.1 and 2). Uncertainty was considered via the production, in parallel, of four sets of predictions, issued from various combinations of transfer parameters values and media concentrations (Table 6). The data set $2 \mathrm{~b}$ in Table 6 corresponds to the 'individual DCC' approach discussed above. Aside from the difference in daughter radionuclides considered, EDEN and the ERICA Tool have been shown to generally give comparable results (Vives i Batlle et al., 2011). 


\section{Estimation of missing concentrations}

\begin{tabular}{|c|c|c|c|}
\hline Data set & Transfer parameters & In water & In sediment \\
\hline 1 & $\begin{array}{l}\text { ERICA Kd values with } \\
\mathrm{CR}_{\text {wo-water }} \text { being taken } \\
\text { from IAEA } \\
\text { except } \mathrm{Pa} \text { and Ac (Table } \\
\text { 3) }\end{array}$ & $\begin{array}{l}\text { from sediment applying } \\
\text { the Kd's }\end{array}$ & $\begin{array}{l}{ }^{234} \mathrm{Th},{ }^{234} \mathrm{U},{ }^{230} \mathrm{Th}={ }^{238} \mathrm{U} \\
{ }^{210} \mathrm{Po}={ }^{210} \mathrm{~Pb} \\
{ }^{235} \mathrm{U}=0.047 \mathrm{x}{ }^{238} \mathrm{U} \\
{ }^{231} \mathrm{~Pa},{ }^{227} \mathrm{Ac},{ }^{227} \mathrm{Th},{ }^{223} \mathrm{Ra}={ }^{235} \mathrm{U} \\
{ }^{226} \mathrm{Ra} \text { from water applying the Kd }\end{array}$ \\
\hline $2 \mathrm{a}$ & Same as 1 & $\begin{array}{l}{ }^{234} \mathrm{Th},{ }^{234} \mathrm{U},{ }^{230} \mathrm{Th}={ }^{238} \mathrm{U} \\
{ }^{210} \mathrm{Po},{ }^{210} \mathrm{~Pb}={ }^{226} \mathrm{Ra} \\
{ }^{235} \mathrm{U}=0.047 \times \mathrm{x}{ }^{238} \mathrm{U} \\
{ }^{231} \mathrm{~Pa},{ }^{227} \mathrm{Ac},{ }^{227} \mathrm{Th},{ }^{223} \mathrm{Ra}= \\
{ }^{235} \mathrm{U}\end{array}$ & Same as 1 \\
\hline $2 b$ & Same as 1 & $\begin{array}{l}\text { Same as 2a except } \\
{ }^{210} \mathrm{Po},{ }^{210} \mathrm{~Pb}=0.4 \mathrm{x}^{226} \mathrm{Ra} \\
\text { (Rn degassing) }\end{array}$ & From water applying the Kd's \\
\hline $3 *$ & $\begin{array}{l}\text { Site specific except } \mathrm{Pa} \\
\text { and Ac (Table } 3)\end{array}$ & Same as 1 & Same as 1 \\
\hline $4 a$ & Same as 3 & Same as $2 \mathrm{a}$ & Same as $2 \mathrm{a}$ \\
\hline $4 \mathrm{~b}$ & Same as 3 & Same as $2 b$ & Same as $2 b$ \\
\hline
\end{tabular}

* Canadian Mining exercise IV (IAEA, in-press)

297 All sets of calculation hypotheses used with the ERICA Tool result in the ${ }^{238} \mathrm{U}$ family dominating the total dose rates experienced for fish, varying from 91 to 100\% (Fig.7B). In contrast, for the mollusc, the organism closely linked to sediment, the ${ }^{235} \mathrm{U}$ contribution increases from $6 \%$ to $75 \%$ respectively from the first to fourth dataset (Fig.7A). As discussed before, the most significant factor contributing to these differences is the derivation of the water and sediment inputs. The more realistic scenarios, where measured media data and site specific transfer parameters were input when available (i.e. data sets $2 \mathrm{a}, 4 \mathrm{a}$ and $4 \mathrm{~b}$ ), resulted in the highest estimated contributions from the ${ }^{235} \mathrm{U}$-series. Absorbed internal dose rates from ${ }^{223} \mathrm{Ra}$ dominated (the DCC for ${ }^{223} \mathrm{Ra}$ includes contributions to dose from ${ }^{219} \mathrm{Rn}$, ${ }^{215} \mathrm{Po},{ }^{211} \mathrm{~Pb},{ }^{211} \mathrm{Bi}$ and $\left.{ }^{207} \mathrm{Tl}\right)$. These $\mathrm{Po}$ and $\mathrm{Bi}$ isotopes were consistently identified as major contributors to the internal and total exposure of Pisidium applying the individual DCC approach. 
Dose rate obtained with the ERICA Tool for a given radionuclide is logically sensitive to the transfer parameter value. Site specific values result in higher U-isotope dose rates for fish (by a factor of $~ 30$ ) but lower Th-isotope dose rates (by a factor of $\sim 15$ ). This effect is smoothed when summing dose rates assessed for each radionuclide to obtain total dose rates. For instance, estimated total dose rates using data set $2 \mathrm{a}$ (literature $\mathrm{CR}$ and $\mathrm{Kd}$ values) and data set $4 \mathrm{a}$ (site specific $\mathrm{CR}$ and $\mathrm{Kd}$ values) are within a factor of two to 10 of each other for fish and mollusc respectively.

We demonstrated that realistic scenarios may lead to a contribution of the ${ }^{235} \mathrm{U}$ family to dose rates which, far from being negligible, may become the dominant source of exposure. This is definitively illustrated by the most realistic assessment conducted for Keddy Bay (data set 3; IAEA, in-press), for which the ${ }^{235} \mathrm{U}$ family produced more than $70 \%$ of the total dose rate for the mollusc. Ignoring this decay chain may result in underestimations of the radiological risk for the environment. This is particularly true for wildlife closely linked with sediment, especially when decay equilibrium is reached there. However, we should also acknowledge that ${ }^{223} \mathrm{Ra}$, the main contributor to dose of the ${ }^{235} \mathrm{U}$-series radionuclides obtained with the ERICA Tool, has a relatively short physical half-life $(\sim 11$ days). Hence equilibrium will not be achieved between tissues and environmental concentrations, i.e. internal dose rates may not be as high as estimated here. Therefore, the present study should be seen as an exercise to assess what could be the consequence of not taking into account ${ }^{235} \mathrm{U}$ and its decay products when assessing biota exposure to radiation. Even if ecological risks appear to be higher for chemical toxicity than radiological toxicity, at least for natural uranium (Mathews et al., 2009), there is a need for a complete characterization of the hazardous nature of uranium. Fully integrating all associated contaminants and pathways is the only way to provide a robust demonstration of the level of associated radiological risk to fauna and flora.

\subsection{Decay equilibrium in water as opposed to sediments}

If decay equilibrium is considered in water of the Keddy Bay scenario, activity concentrations of the $U$ chain members in the mollusc (Fig. 8, upper graph) vary generally from $10^{1}$ (lead isotopes, ${ }^{235} \mathrm{U}$, ${ }^{227} \mathrm{Ac} .$. ) to $10^{3}-10^{4}$ (Th isotopes, ${ }^{215} \mathrm{Po},{ }^{211} \mathrm{Bi}$, etc.) $\mathrm{Bq} \mathrm{kg}^{-1}$ fresh mass (fm). Radon is an exception, 
exhibiting especially low values $\left(10^{-3}\right.$ to $\left.10^{-2} \mathrm{~Bq} \mathrm{~kg}^{-1} \mathrm{fm}\right)$ due to a low assumed $\mathrm{CR}$. A somewhat similar pattern is observed for pike, which presents lower activity concentrations for all radionuclides. Conversion into dose rate preserves partly the relative isotope distribution (Fig. 8, lower graphs), which explains the contribution of the ${ }^{235} \mathrm{U}$ family to total dose rate close to $40 \%$.

Assuming decay equilibrium in sediment changes drastically both the activity concentrations and dose rate distributions. This hypothesis increases the importance of chain members beyond radon. $\mathrm{Po}, \mathrm{Pb}$ and Bi isotopes are estimated to have high activity concentrations in Pisidium and pike, up to four orders of magnitude higher than those of the chain parents. Measured data were too scarce to support the validation of one assumption vs the other (i.e. decay equilibrium in water rather than in sediment, or vice versa).

Considering decay equilibrium in water, the theoretical assumption of equilibrium throughout the two decay chains led to a contribution of the ${ }^{235} \mathrm{U}$ family to total dose rates of $4 \%$ for both organisms. Compared to this result, this estimated contribution is increased in our case study (from 16 to $40 \%$ depending on occupancy factors for pike) due to the large disequilibrium between ${ }^{238} \mathrm{U}$ and ${ }^{226} \mathrm{Ra}$, the concentration of the latter being two orders of magnitude lower than expected when considering decay equilibrium. Consequently, all its daughter products activity concentrations are also estimated to be two orders of magnitude lower, increasing the relative part of total dose rates due to the ${ }^{235} \mathrm{U}$ family. Predicted ${ }^{235} \mathrm{U}$ concentrations in water are about one order of magnitude higher than those of ${ }^{226} \mathrm{Ra}$. These concentrations exceeded those of the members at the end of the ${ }^{238} \mathrm{U}$ chain, explaining the difference observed between the theoretical calculation and the case study results.

\section{Conclusions}

We obtained from both the theoretical (assumption of isotope equilibria) and more realistic (inclusion of available site data) approaches significant contributions of the ${ }^{235} \mathrm{U}$ family, up to $75 \%$ of the estimated total dose rate experienced by an organism. These results contradict the common opinion that doses rates from the ${ }^{235} \mathrm{U}$ series radionuclides may be neglected compared to those from the ${ }^{238} \mathrm{U}$ series radionuclides. While many aspects of the present work are uncertain and use simplistic 
assumptions there is a weight of evidence that ${ }^{235} \mathrm{U}$-series radionuclides have the potential to make important contributions to dose rates.

Given the current state of knowledge, we were not able to improve on our assessment (presented here) of the ${ }^{235} \mathrm{U}$ family contribution to dose rate assessment for non-human biota. This exercise nevertheless shows the need for determining the actual state of decay equilibrium of these chains, at least for some characteristic situations. To understand the contribution of the ${ }^{235} \mathrm{U}$ family further, it is essential to ensure a high quality of validated measurement methods. In addition to assessments of contaminated sites this conclusion has implications for current background exposure rates estimated for wildlife due to natural series radionuclides (e.g. Hosseini et al., 2010; Beresford et al., 2008) as these do not take the ${ }^{235} \mathrm{U}$ series into account.

The final conclusion of this work concerns the best way to limit estimation bias identified when dealing individually or globally with decay chain members during dose rate assessment. The most realistic result should be obtained with a combination of the two studied approaches, applying family internal DCCs to realistic parent nuclide concentrations in organisms and individual external DCCs to media activity concentrations of individual daughter products.

\section{Acknowledgments}

This work was partly undertaken within the framework of the IAEA EMRAS II programme. The authors would like to thank all members of the group, for the interesting and fruitful discussions the presentations of this work generated. The input of N.A. Beresford to this work was facilitated through CEH National Capability funding.

\section{References}

Beaugelin-Seiller, K., Jasserand, F., Garnier-Laplace, J., Gariel, J.C., 2006. Modelling the radiological dose in non-human species: principles, computerization and application, Health Phys. 90: 485-493. 
Beresford, N.A., Brown, J.E., Copplestone, D., Garnier-Laplace, J., Howard, B.J., Larsson, C-M., Oughton, O., Pröhl, G., Zinger, I. (eds.) 2007. D-ERICA: An integrated approachto the assessment and management of environmental risks from ionising radiation. Description of purpose, methodology and application. Contract Number: FI6R-CT-2003-508847, 82 p+ annexes.

Beresford, N.A., Barnett, C.L., Jones, D.G., Wood, M.D., Appleton, J.D., Breward, N., Copplestone D. (2008). Background exposure rates of terrestrial wildlife in England and Wales. J. Environ. Radioact., 99: 1430-1439.

Beresford, N.A., Barnett, C.L., Vives i Batlle, J., Potter, E.D., Ibrahimi, Z.-F., Barlow, T.S., Schieb, C., Jones, D.G., Copplestone, D. (2012). Exposure of burrowing mammals to ${ }^{222} \mathrm{Rn}$. Sci. Tot. Environ.. 431: 252-261.

Bopp, C.J. IV, Lundstrom, C.C., Johnson, T.M., Glessner, J.J.G. (2009). Variations in ${ }^{238} \mathrm{U} /{ }^{235} \mathrm{U}$ in uranium ore deposits : Isotopic signatures of the U reduction process? Geology July 2009

Brown, J.E, Jones, S.V., Saxen, R., Thorring, H., Vives I Batlle, J. (2004). Radiation doses to aquatic organisms from natural radionuclides. J. Radiol. Prot., 24: A63-A77.

Brown, J.E., Alfonso, B., Avila, R., Beresford, N.A., Copplestone, D., Pröhl, G., Ulanovsky A. (2008). The ERICA Tool. J. Environ. Radioact., 99, 1371-1383.

Brown, J.E, Beresford, N.A. Hosseini, A. (2013). Approaches to providing missing transfer parameter values in the ERICA Tool - How well do they work? J. Environ. Radioact. 126, 399-411.

Canada North Environmental Services, 2003. Beaverlodge decommissioning: Results of the fall 2002 aquatic biological investigations at the Dubyna Mine site area, Northern Saskatchewan, in. Cameco, Saskatoon, Saskatchewan, Canada, pp. 143-282.

Canada North Environmental Services, 2005. Beaverlodge Decommissioning: Fulton Creek Watershed 2004 Current Environmental Aquatic Investigations, in: 05-1271/05-1272 ed. Cameco, Saskatoon, Saskatchewan, Canada, pp. 1-179. 
Copplestone, D., Beresford, N.A., Brown, J.E., Yankovich, T. (2013). An international database of radionuclide concentration ratios for wildlife: Development and uses. J. Environ. Radioactiv., 126, pp 288-298.

Cossonnet, C., Agarande, M., Bérard, P., Franck, D., Montégue, A., Perrin, M.-L., Witschger, O. (2001) Métrologie de l'uranium. In L'Uranium: de l'environnement à l'homme, Métivier, H., Ed. EDP Sciences: Les Ulis,; pp 145-186.

Cowan, G.A., Adler, H.H (1976). The variability of the natural abundance of ${ }^{235}$ U. Geochim. Cosmochim. Acta 40, 1487-1490

Del Papa, C., Krishbaum, A., Powell, J., Brod, A., Hongn, F., Pimentel, M. (2010). Sedimentological, geochemical and paleontological insights applied to continental omission surfaces: A new approach for reconstructing an Eocene foreland basin in NW Argentina. J. S. Am. Earth Sci. 29, 327-345.

Funk, A., Reckendorfer, W. (2008). Environmental heterogeneity and morphological variability in Pisidium subtruncatum (Sphaeriidae, Bivalvia). International Review of Hydrobiology 93, 188-199.

Golder Associates (2006). Beaverlodge Lake/Fulton Bay Fish Health, Spawning inventory, and habitat assessment Fall 2005 program, in: 05-1365-032 ed. Cameco, Saskatoon, Saskatchewan, Canada, pp. 1176.

Golder Associates (2008). Technical Information document for the inactive Lorado Uranium Tailings Site., in: 04-1360-001B ed. Saskatchewan Reseach Council, Saskatoon, Saskatchewan, Canada, pp. 1851.

Hosseini, A., Beresford, N.A., Brown, J.E., Jones, D.G., Phaneuf, M., Thørring, H., Yankovich, T. (2010). Background dose-rates to reference animals and plants arising from exposure to naturally occurring radionuclides in aquatic environments J. Radiol. Prot. 30 (2010) 235-264.

ICRP (1993). Age-dependent doses to members of the public from intake of radionuclides: Part 2 Ingestion dose coefficients. International Commission on Radiological Protection Publication 67, Pergamon Press. 
ISCORS (2004). RESRAD-BIOTA: A Tool for Implementing a Graded Approach to Biota Dose Evaluation. USER'S GUIDE, VERSION 1. DOE/EH-0676, U.S. Department of Commerce, Technology Administration, National Technical Information Service, Springfield, VA 22161.

IAEA (2001). Generic Models for Use in Assessing the Impact of Discharges of Radioactive Substances to the Environment. Safety Reports Series $n^{\circ} 19$, International Atomic Energy Agency, Vienne, $216 \mathrm{p}$.

IAEA (2014). Handbook of Parameter Values for the Prediction of Radionuclide Transfer to Wildlife. Technical Reports Series n479, International Atomic energy Agency, Vienna, 211p.

IAEA (in-press). Modelling dose to benthic invertebrates and fish near Canadian operating and decommissioned Uranium mines and mills. Report of Working Group "Biota Modelling" of EMRAS II Topical Heading "Reference Approaches for Biota Dose Assessment". International Atomic energy Agency, Vienna, 60p.

Kilgour, B.W., Mackie, G.L., 1991. Relationships Between Demographic Features of A Pill Clam (Pisidium casertanum) and Environmental Variables. Journal of the North American Benthological Society 10, 68-80.

Lucas, H.F., Jr., Simmons, D., Markun, F., Farnham, J., Keenan, M. (1979). Radon and radium retention by the bluegill. Health Phys. 36, 147-152.

Mathews T., Beaugelin-Seiller K., Garnier-Laplace J., Gilbin R., Adam C. et Della-Vedova C. (2009). A Probabilistic Assessment of the Chemical and Radiological Risks of Chronic Exposure to Uranium in Freshwater Ecosystems. Environ.Sci.Technol.43(17): 6684-6690.

Pröhl, G., Brown, J., Gomez-Ros, J.-M., Jones, S., Taranenko, V., Thørring, H., Vives i Batlle, J., Woodhead, D. (2003). Dosimetric models and data for assessing radiation exposures to biota. Deliverable 3, FASSET project, Contract No FIGE-CT-2000-00102.

Richter, S., Alonso, A., De Bolle, W., Wellum, R, Taylor, P.D.P. (1999). Isotopic « fingerprints » for natural uranium ore samples. Int. J. Mass. Spectrom. 193, 9-14. 
Sabroux J.C. (1998). Le radon, traceur de phénomènes naturels. In : Le radon, de l'environnement à l’homme, Métivier H. and Robé M.C., Ed. EDP Sciences, Les Ulis, pp 31-53.

Sheppard, S.C., Herod, M. (2012). Variation in background concentrations and specific activities of ${ }^{36} \mathrm{Cl},{ }^{129} \mathrm{I}$ and U/Th series radionuclides in surface waters. J. Environ. Radioactiv. 106, 27-34.

Staven, L.H., Rhoads, K., Napier, B.A., Strenge, D.L. (2003). A Compendium of Transfer Factors for Agricultural and Animal Products. Pacific Northwest Laboratory for US Department of Energy, PNNL-13421, Richland, Washington, USA.

Stirling, C.H., Andersen, M.B., Potter, E., Halliday, A.N. (2007). Low-temperature isotopic fractionation of uranium. Earth Planet. Sc. Lett. 264, 208-225.

Sun, W., Zhou, M., Yan, D., Li, J. Ma, Y. (2008). Provenance and tectonic setting of the Neoproterozoic Yanbian Group, western Yangtze Block (SW China). Precambrian Res. 167, 213-236.

Ulanovski, A., Pröhl, G., Gomes-Ros, J.C (2008). Methods for calculating dose conversion coefficients for terrestrial and aquatic biota. J. Environ. Radioactiv. 99: 1440-1448

Vives i Batlle, J., Balonov, M., Beaugelin-Seiller, K., Beresford, N.A., Brown, J., Cheng, J.J., Copplestone, D., Doi, M., Flistovic, V., Golokiv, V., Horyna, J., Hosseini, A., Howard, B.J., Jones, S.R., Kamboj, S., Kryshev, A.I., Nedveckaite, T., Olyslaegers, G., Prohl, G., Sazykina, T.G., Ulanovski, A., Vives-Lynch, S., Yankovich, T., Yu, C. (2007) Inter-comparison of unweighted absorbed dose rates for non-human biota. Radiat. Environ. Bioph. 46 (4): 349-373.

Vives i Batlle, J., Beaugelin-Seiller, K., Beresford, N.A., Copplestone, D., Horyna, J., Hosseini, A., Johansen, M., Kamboj, S. Keum, D-K., Kurosawa, N., Newsome, L., Olyslaegers, G., Vandenhove, H., Ryufuku, S., Vives Lynch, S., Wood, M.D., Yu, C. (2011). The estimation of absorbed dose rates for non-human biota: an extended intercomparison. Radiat. Environ. Biophys. 50: 231-251

Wang, X.K., Dong, W.M., Zang, H.X., Tao, Z.Y. (2001) A multitracer study on the adsorption of 36 elements on a silica: Effects of pH and fulvic acid. J Radioanal Nucl Ch, 250 (3): 491-496. 
483 Wang, X.K., Dong, W.M., Tao, Z.Y. (2003) A multitracer study on the adsorption of 32 elements on a 484 natural hematite (a-Fe2O3): effects of $\mathrm{pH}$ and fulvic acid. Colloid Surface A 223: 135-143.

485 Weyer, S., Anbar, A.D., Gerdes, A., Gordon, G.W., Algeo, T.J., Boyle, E.A. (2008). Natural 486 fractionation of 238U/235U. Geochim. Cosmochim. Acta. 72: 345-359.

487 
Figure 1: ${ }^{238} \mathrm{U}$ decay chain (italic text: half-life; normal text: branching ratio (BR); grey lines: secondary decay chain with first daughter BR less than 0.9; solid grey boxes: stable element; Nucleonica GmBH, 2015)

Figure 2: : ${ }^{235} \mathrm{U}$ decay chain (italics: half-life, normal: branching ratio -BR; grey lines: secondary decay chain with first daughter BR less than 0.9; grey box: stable element; Nucleonica GmBH, 2015)

Figure 3: Theoretical activity concentrations per isotope, based on $\mathrm{Kd}$ and CR values, in water vs. sediment (upper graph) and water vs. organisms (lower graph), considering a unit activity concentration of ${ }^{238} \mathrm{U}$ in water where decay equilibrium is achevied in all daughters and considering the ${ }^{235} \mathrm{U}$ decay chain.

Figure 4: Distributions of media concentrations of radionuclides at Keddy Bay (decay chains at equilibrium in water - upper graph- or in sediment - lower graph; black bar: data extrapolated from ${ }^{238} \mathrm{U}$ concentration, grey bar: measurements completed by extrapolations)

Figure 5: Contribution $(\%)$ to total dose rates per member of the uranium decay chains for benthic invertebrate (Pisidium at the water/sediment interface or in sediment) and fish (pike in water), considering equilibrium either in water (upper graph) or in sediment (lower graph), from an initial theoretical unit concentration of ${ }^{238} \mathrm{U}$ (only main contributors are identified on the graphs).

Figure 6: Contribution (\%) to total dose rates per member of the uranium decay chains for benthic invertebrate (Pisidium at the water/sediment interface) and fish (pike in water), considering equilibrium either in water (upper graph) or in sediment (lower graph), at Keddy Bay (only main contributors are identified on the graphs).

Figure 7: ${ }^{235} \mathrm{U}$ family contribution (light grey) vs. other contribution (dark grey) to the total dose rate to organisms (A: mollusc; B: fish) as estimated with the ERICA tool for the combinations of transfer parameters and media concentrations in Table 6

Figure 8: Distribution per radionuclide of activity concentrations (upper graphs) and dose rates (lower graphs) for Pisidium (on the left) and pike (on the right) at Keddy Bay (decay equilibrium in water -black bar- or in sediment white bar) 
Figure 1

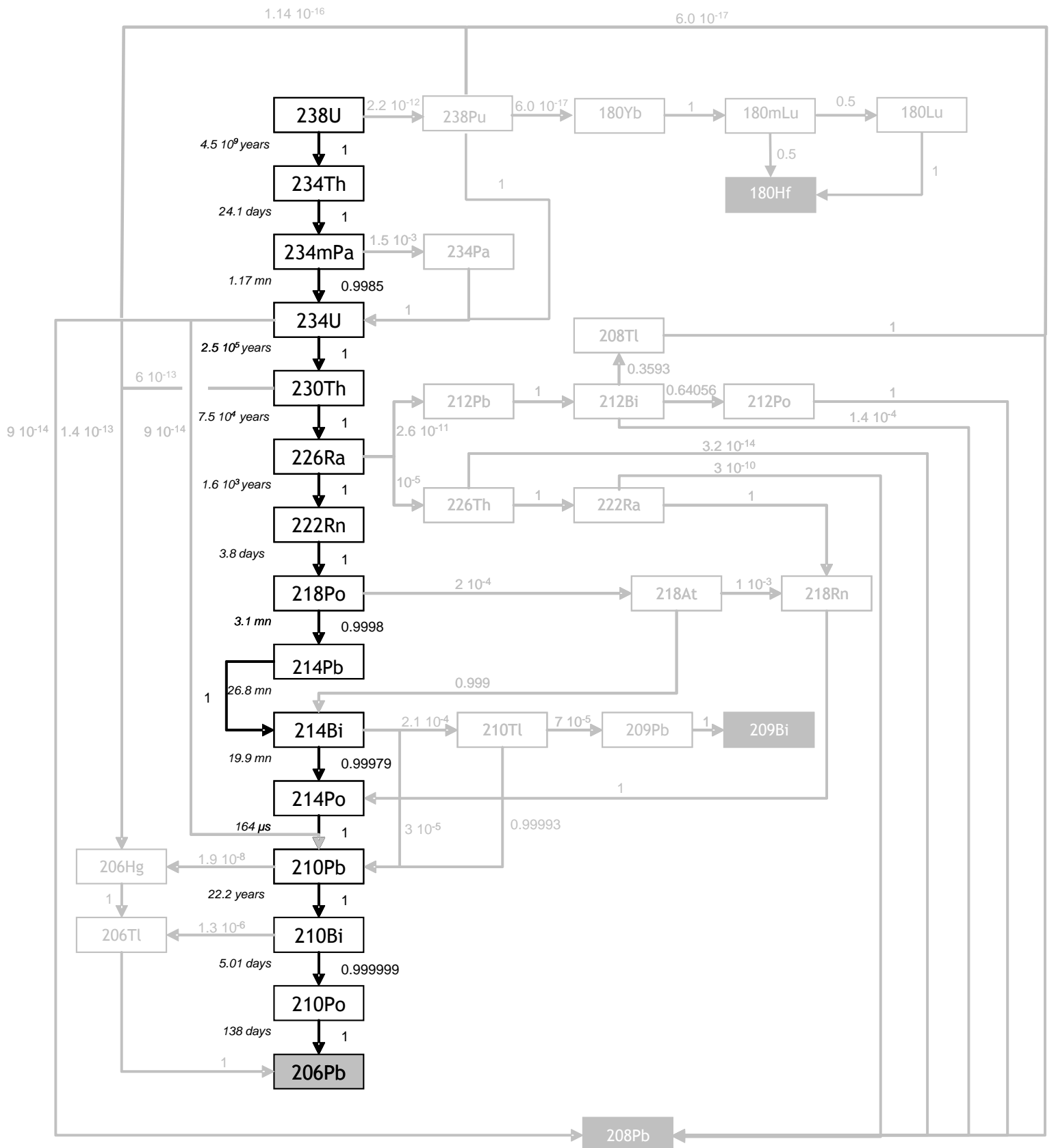


Figure 2

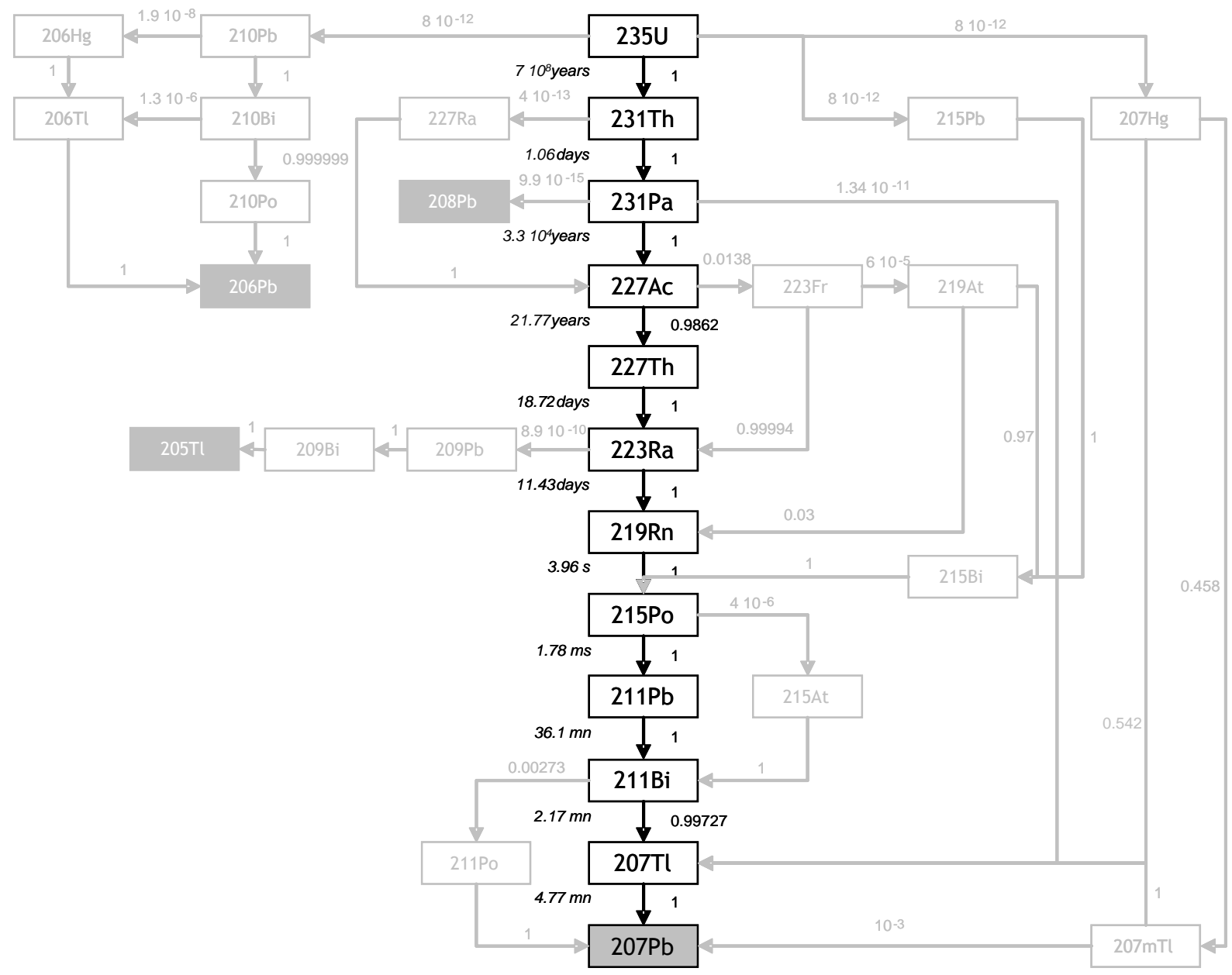


Figure 3
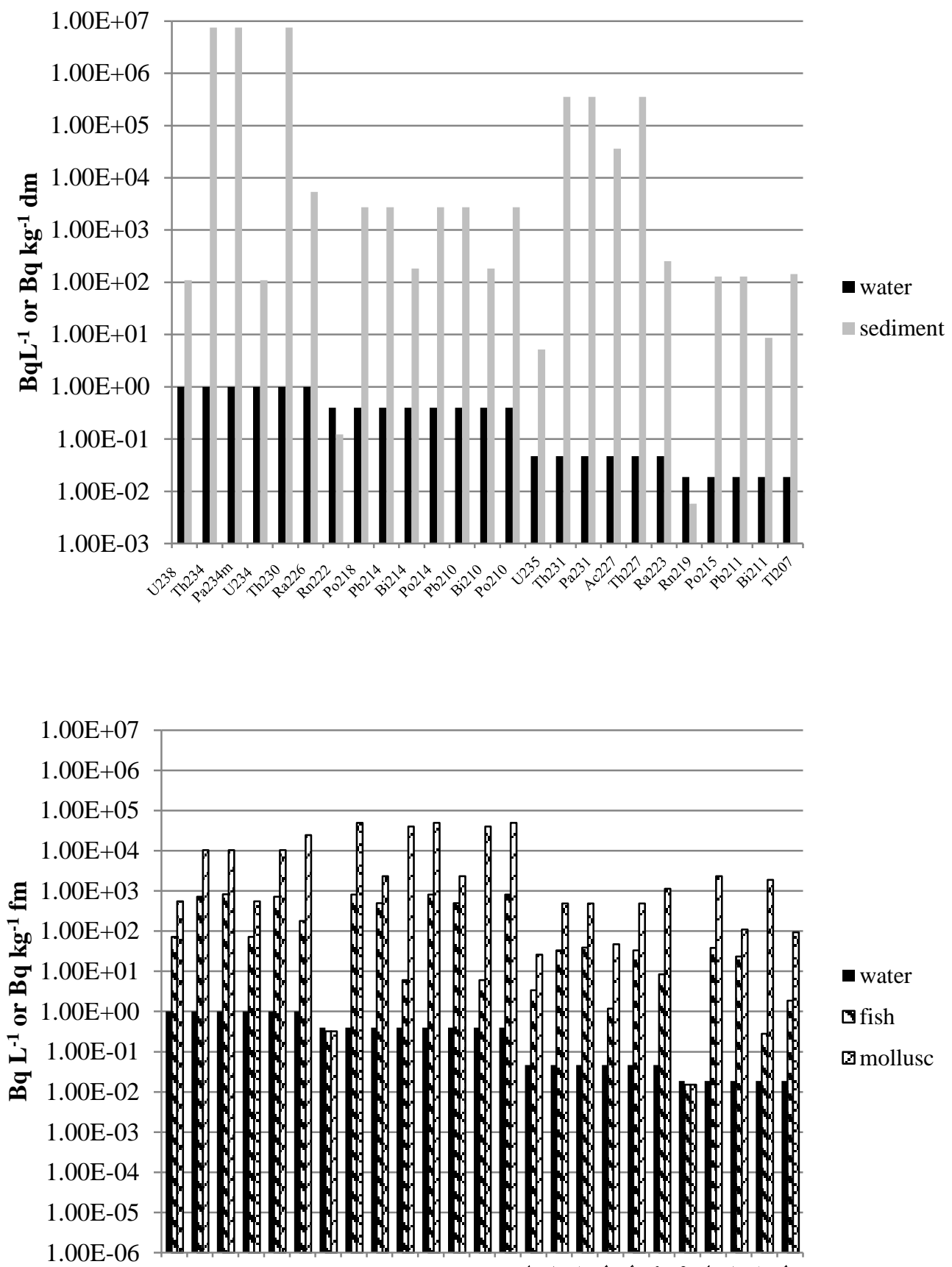

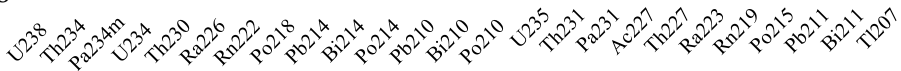


Figure 4

\section{Decay chains at equilibrium in water}

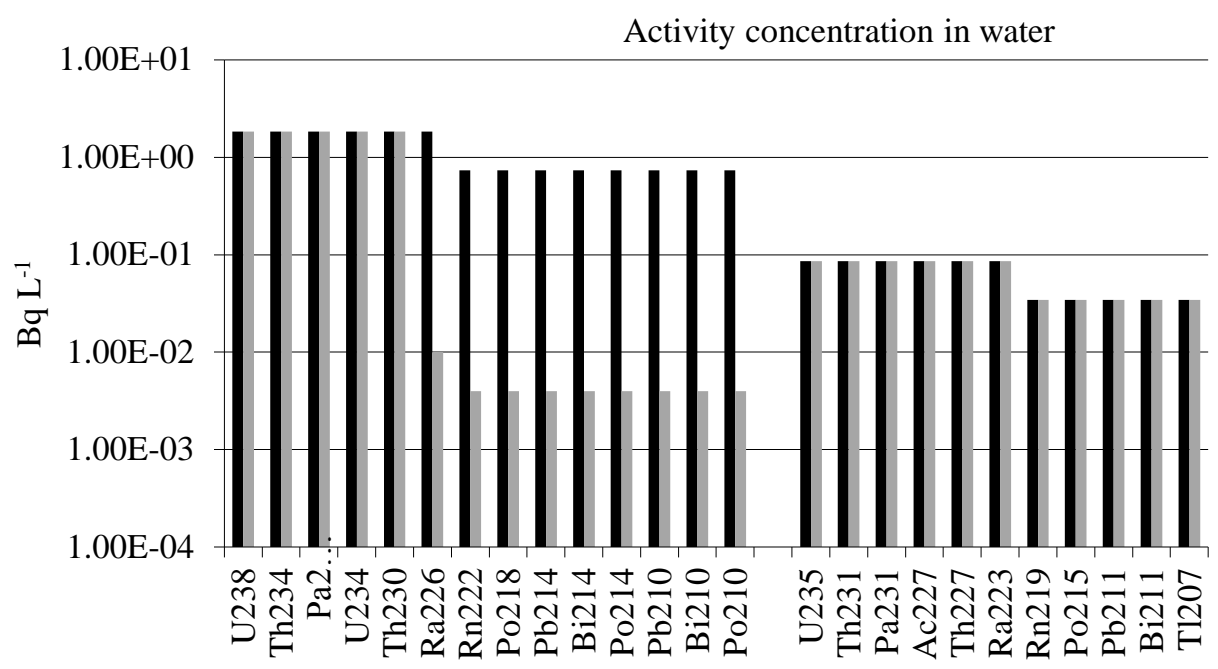

Decay chains at equilibrium in sediment

Activity concentration in sediment

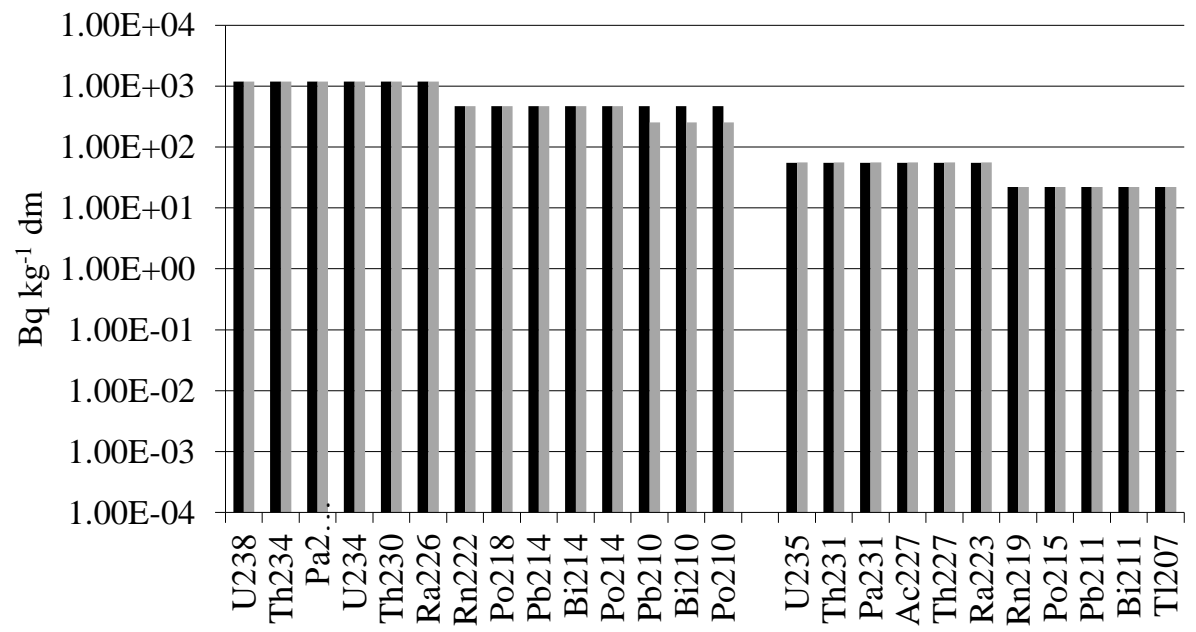


Figure 5

Contribution of the $\mathrm{U}-235$ decay chain

Decay chains at equilibrium in water

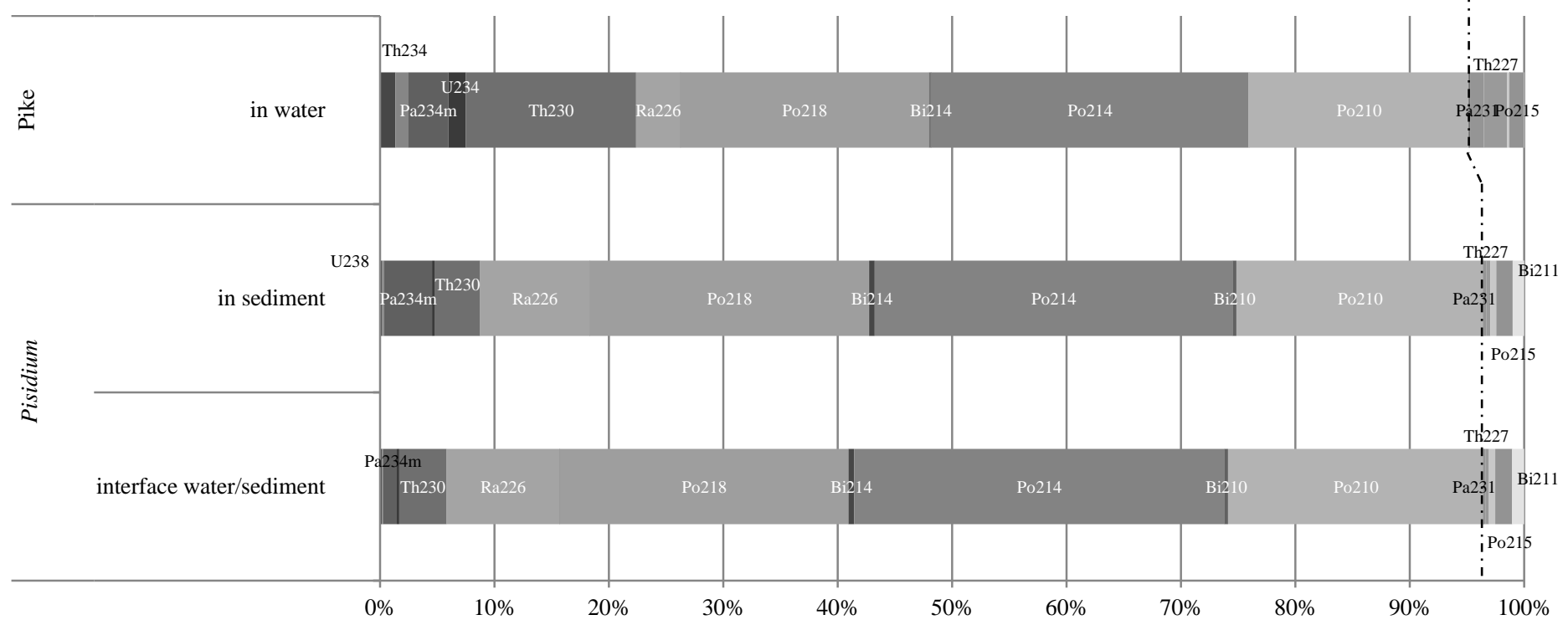

Decay chains at equilibrium in sediment

Contribution of the U-235 decay chain

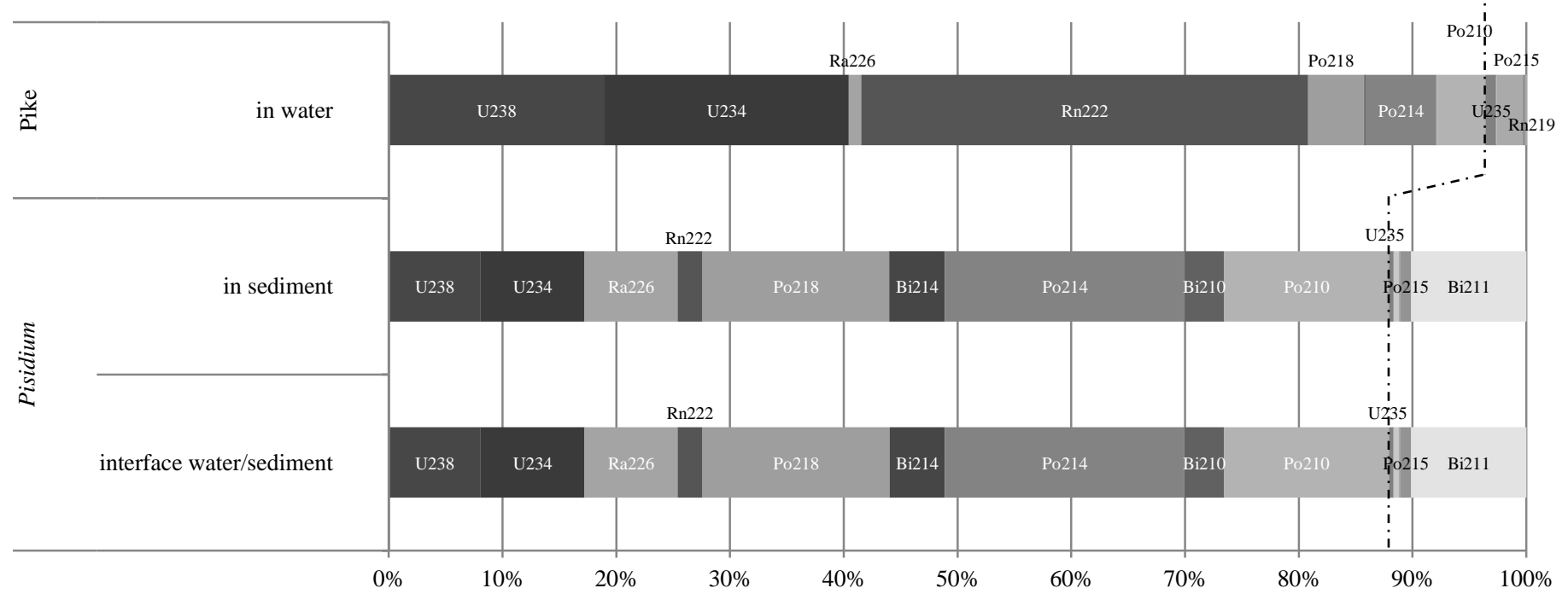

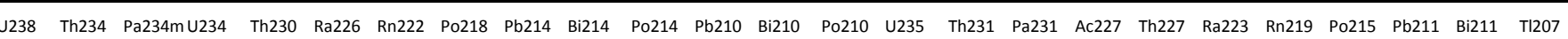


Figure 6

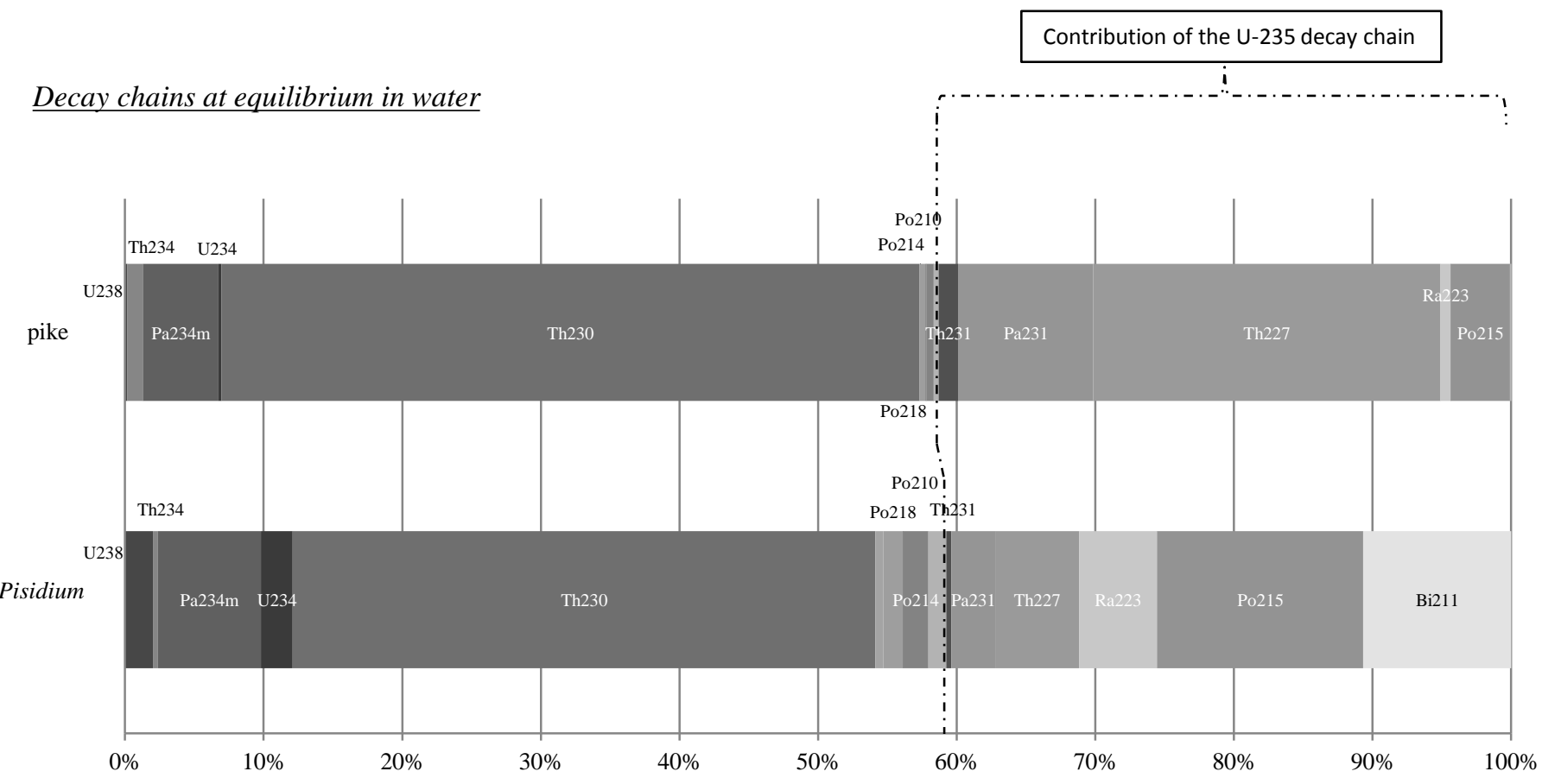

\section{Decay chains at equilibrium in sediment}

Contribution of the U-235 decay chain

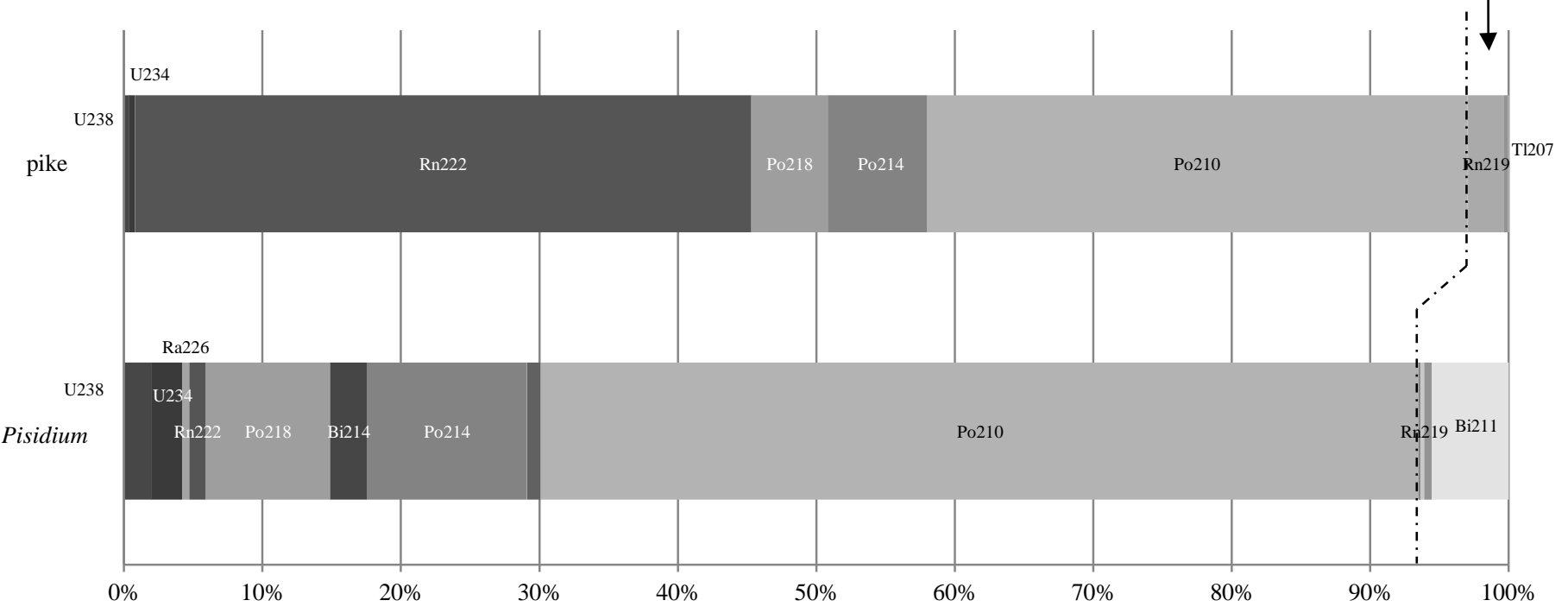

\begin{tabular}{lllllllllllllllllllllllllllll}
\hline 238 & Th234 & Pa234mU234 & Th230 & Ra226 & Rn222 & Po218 & Pb214 & Bi214 & Po214 & Pb210 & Bi210 & Po210 & U235 & Th231 & Pa231 & Ac227 & Th227 & Ra223 & Rn219 & Po215 & Pb211 & Bi211 & Tl207
\end{tabular} 
Figure 7

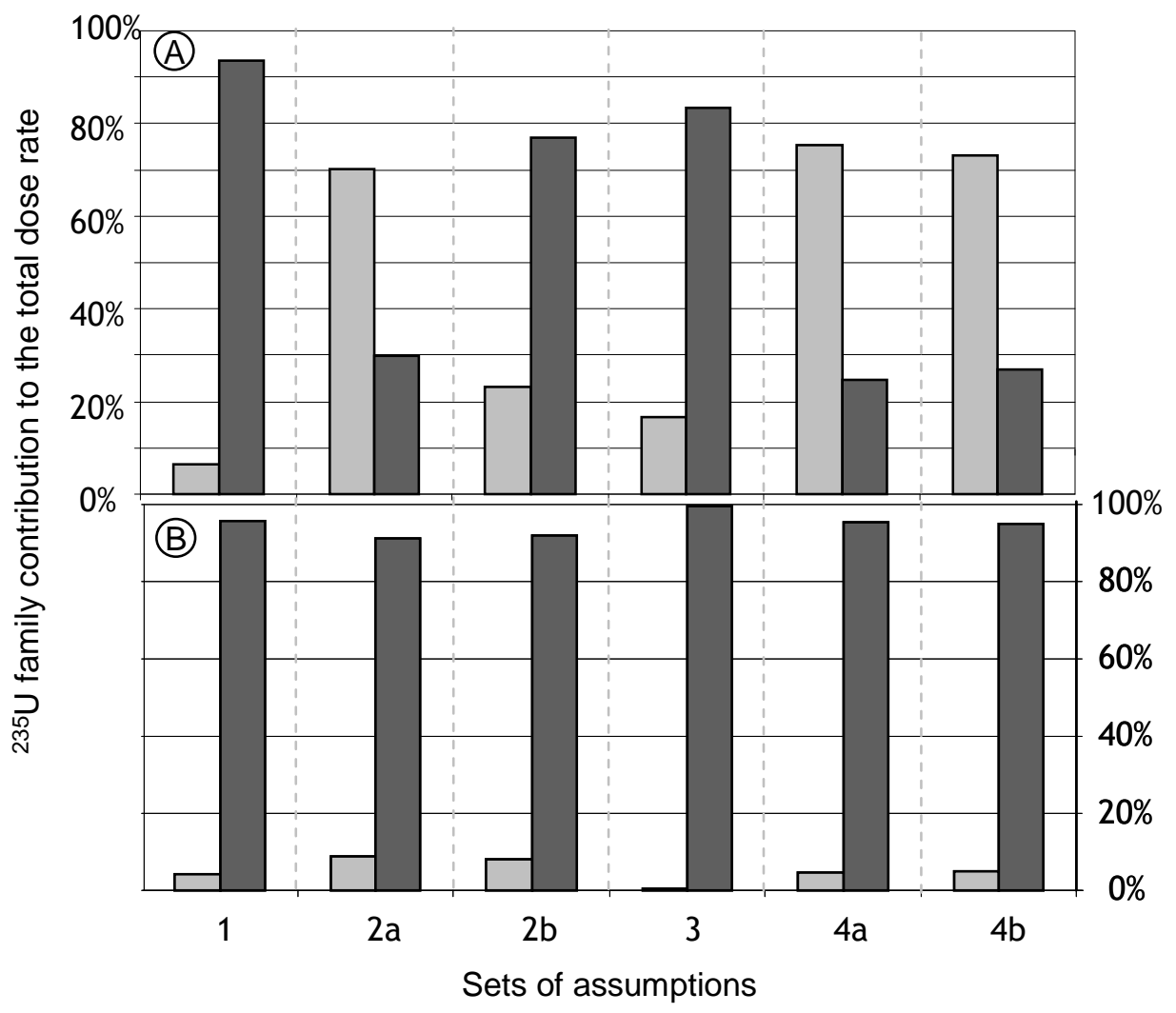


Figure 8

Activity concentration $\left(\mathrm{Bq} \mathrm{kg}^{-1} \mathrm{fm}\right)$
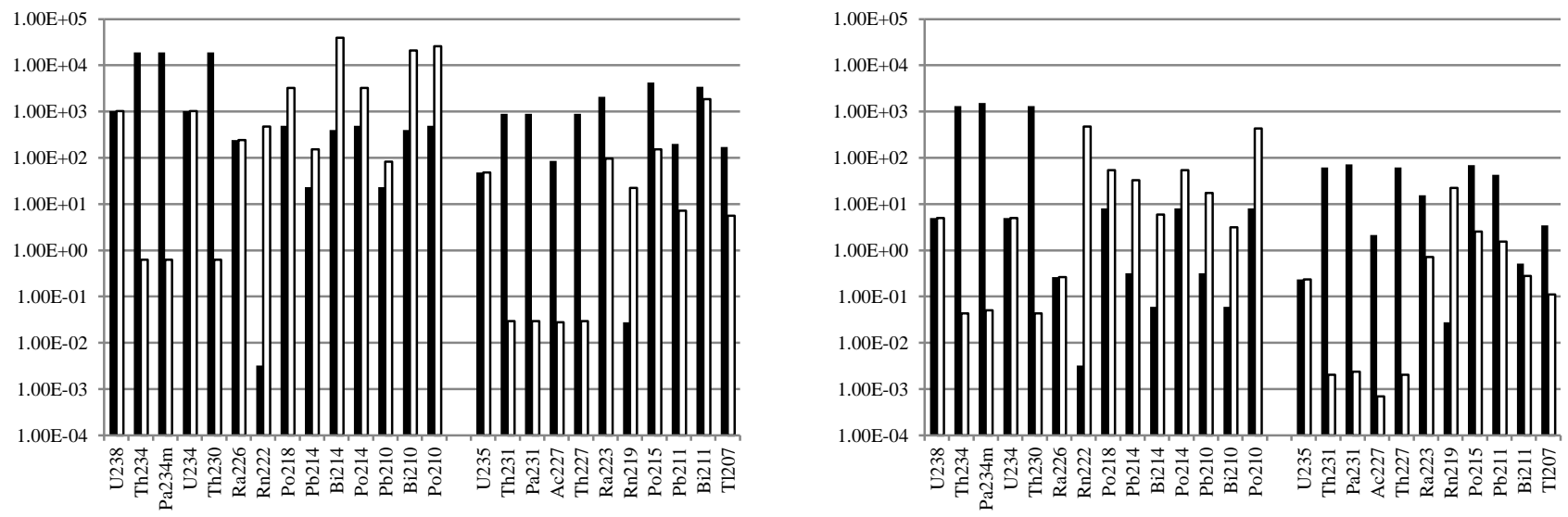

Total dose rate $\left(\mu \mathrm{Gy} \mathrm{h}^{-1}\right)$
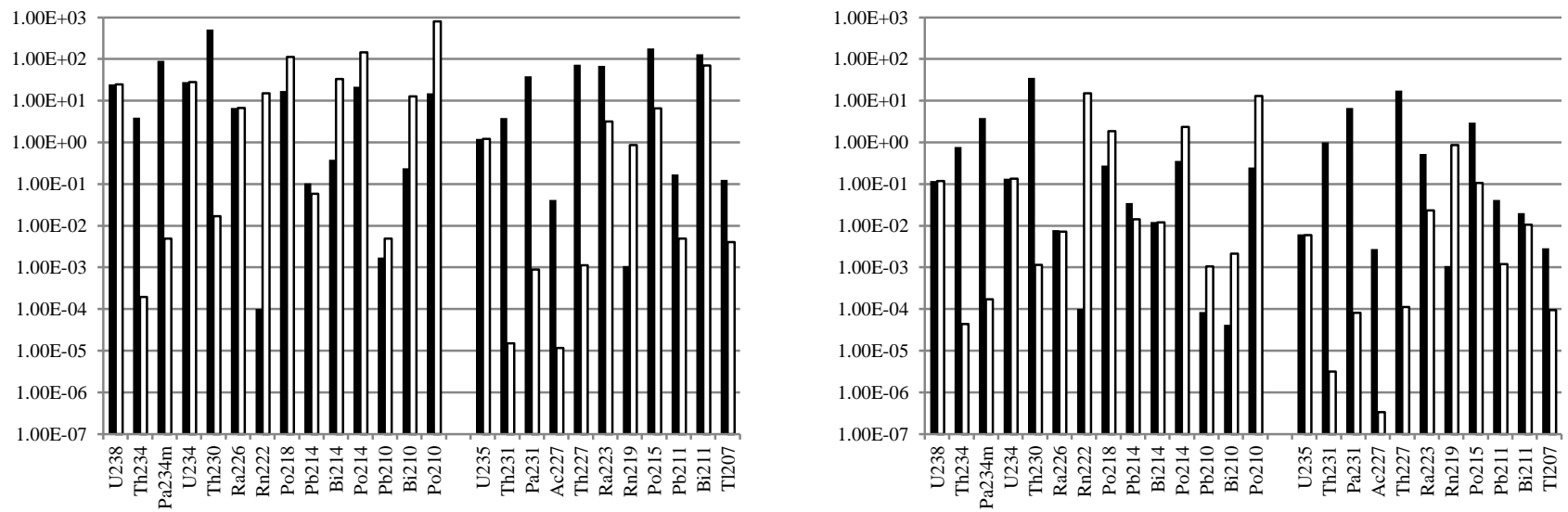


\section{Should we ignore U-235 series contribution to dose?}

\section{Supplementary material}

Table A1: weighted DCCs ( 1 to $\gamma$ DCC, 3 to $\beta$ DCC and 10 to $\alpha$ DCC) calculated with EDEN 2.2 (organism: $\mu \mathrm{Gy} \mathrm{h}^{-1}$ per Bq kg${ }^{-1}$ wm; water: $\mu \mathrm{Gy} \mathrm{h}^{-1}$ per Bq $\mathrm{L}^{-1}$; sediment: $\mu \mathrm{Gy} \mathrm{h}^{-1}$ per Bq kg${ }^{-1}$ wm)

\begin{tabular}{|c|c|c|c|c|c|c|c|c|}
\hline \multirow{4}{*}{$\begin{array}{l}\text { Organism } \\
\text { Exposure } \\
\text { Location } \\
\text { Source } \\
\end{array}$} & \multicolumn{4}{|c|}{ Pisidium } & \multicolumn{4}{|c|}{ Pike } \\
\hline & \multirow[t]{2}{*}{ internal } & \multicolumn{3}{|c|}{ external } & \multirow[t]{2}{*}{ internal } & \multicolumn{3}{|c|}{ external } \\
\hline & & \multirow{2}{*}{$\begin{array}{c}\text { In water } \\
\text { water }\end{array}$} & \multicolumn{2}{|c|}{ On sediment } & & In water & \multicolumn{2}{|c|}{ On sediment } \\
\hline & organism & & water & sediment* & organism & water & water & sediment \\
\hline U238 & $2.41 \mathrm{E}-02$ & $4.25 \mathrm{E}-05$ & $4.29 \mathrm{E}-05$ & 2.33E-08 & $2.41 \mathrm{E}-02$ & $4.17 \mathrm{E}-06$ & 4.10E-06 & 3.03E-09 \\
\hline Th234 & $8.00 \mathrm{E}-05$ & $5.17 \mathrm{E}-06$ & 2.67E-06 & $6.46 \mathrm{E}-07$ & $8.13 \mathrm{E}-05$ & $3.46 \mathrm{E}-06$ & $2.50 \mathrm{E}-06$ & $3.55 \mathrm{E}-07$ \\
\hline $\mathrm{Pa} 234 \mathrm{~m}$ & $1.08 \mathrm{E}-03$ & $3.65 \mathrm{E}-04$ & $3.35 \mathrm{E}-04$ & $1.87 \mathrm{E}-05$ & $1.38 \mathrm{E}-03$ & $4.02 \mathrm{E}-05$ & $3.75 \mathrm{E}-05$ & $9.08 \mathrm{E}-07$ \\
\hline $\mathrm{U} 234$ & $2.74 \mathrm{E}-02$ & $6.04 \mathrm{E}-05$ & $6.00 \mathrm{E}-05$ & 3.91E-08 & $2.74 \mathrm{E}-02$ & $5.83 \mathrm{E}-06$ & $5.79 \mathrm{E}-06$ & $5.25 \mathrm{E}-09$ \\
\hline Th230 & $2.68 \mathrm{E}-02$ & $5.71 \mathrm{E}-05$ & $5.71 \mathrm{E}-05$ & 5.83E-08 & $2.69 \mathrm{E}-02$ & 5.63E-06 & $5.54 \mathrm{E}-06$ & $1.82 \mathrm{E}-08$ \\
\hline $\mathrm{Ra} 226$ & $2.75 \mathrm{E}-02$ & $6.42 \mathrm{E}-05$ & $6.21 \mathrm{E}-05$ & 7.38E-07 & $2.75 \mathrm{E}-02$ & 8.67E-06 & 7.83E-06 & $4.96 \mathrm{E}-07$ \\
\hline Rn222 & $3.15 \mathrm{E}-02$ & $8.75 \mathrm{E}-05$ & $8.58 \mathrm{E}-05$ & $9.38 \mathrm{E}-08$ & $3.16 \mathrm{E}-02$ & $8.42 \mathrm{E}-06$ & $8.42 \mathrm{E}-06$ & $3.46 \mathrm{E}-08$ \\
\hline Po218 & $3.45 \mathrm{E}-02$ & $1.10 \mathrm{E}-04$ & $1.10 \mathrm{E}-04$ & 7.58E-08 & $3.45 \mathrm{E}-02$ & $1.06 \mathrm{E}-05$ & $1.05 \mathrm{E}-05$ & $1.42 \mathrm{E}-09$ \\
\hline $\mathrm{Pb} 214$ & $3.65 \mathrm{E}-04$ & $1.36 \mathrm{E}-04$ & $7.79 \mathrm{E}-05$ & $2.80 \mathrm{E}-05$ & 4.08E-04 & $9.96 \mathrm{E}-05$ & $5.75 \mathrm{E}-05$ & $2.04 \mathrm{E}-05$ \\
\hline $\mathrm{Bi} 214$ & $8.46 \mathrm{E}-04$ & $9.08 \mathrm{E}-04$ & $5.67 \mathrm{E}-04$ & $1.93 \mathrm{E}-04$ & $1.18 \mathrm{E}-03$ & $6.33 \mathrm{E}-04$ & $3.49 \mathrm{E}-04$ & $1.07 \mathrm{E}-04$ \\
\hline Po214 & $4.42 \mathrm{E}-02$ & $2.24 \mathrm{E}-04$ & $2.18 \mathrm{E}-04$ & 2.37E-07 & $4.42 \mathrm{E}-02$ & $2.10 \mathrm{E}-05$ & $2.12 \mathrm{E}-05$ & 8.75E-09 \\
\hline $\mathrm{Pb} 210$ & $6.00 \mathrm{E}-05$ & $1.23 \mathrm{E}-06$ & $6.46 \mathrm{E}-07$ & $9.96 \mathrm{E}-08$ & $6.00 \mathrm{E}-05$ & 8.33E-07 & $6.08 \mathrm{E}-07$ & $3.78 \mathrm{E}-08$ \\
\hline $\mathrm{Bi} 210$ & $6.00 \mathrm{E}-04$ & $7.54 \mathrm{E}-05$ & $7.25 \mathrm{E}-05$ & $1.67 \mathrm{E}-06$ & $6.67 \mathrm{E}-04$ & 7.21E-06 & 7.04E-06 & $1.76 \mathrm{E}-08$ \\
\hline Po210 & $3.05 \mathrm{E}-02$ & $8.00 \mathrm{E}-05$ & $7.88 \mathrm{E}-05$ & $4.58 \mathrm{E}-08$ & $3.05 \mathrm{E}-02$ & $7.58 \mathrm{E}-06$ & 7.63E-06 & $1.13 \mathrm{E}-09$ \\
\hline $\mathrm{U} 235$ & $2.53 \mathrm{E}-02$ & $1.29 \mathrm{E}-04$ & 8.88E-05 & $1.72 \mathrm{E}-05$ & $2.54 \mathrm{E}-02$ & $7.50 \mathrm{E}-05$ & $5.54 \mathrm{E}-05$ & $1.20 \mathrm{E}-05$ \\
\hline Th231 & $1.58 \mathrm{E}-04$ & $9.71 \mathrm{E}-06$ & $5.67 \mathrm{E}-06$ & $9.75 \mathrm{E}-07$ & $1.60 \mathrm{E}-04$ & $5.92 \mathrm{E}-06$ & $4.38 \mathrm{E}-06$ & $5.29 \mathrm{E}-07$ \\
\hline $\mathrm{Pa} 231$ & $2.87 \mathrm{E}-02$ & $8.29 \mathrm{E}-05$ & $7.50 \mathrm{E}-05$ & $3.45 \mathrm{E}-06$ & $2.88 \mathrm{E}-02$ & $1.90 \mathrm{E}-05$ & $1.40 \mathrm{E}-05$ & $2.50 \mathrm{E}-06$ \\
\hline Ac227 & $4.09 \mathrm{E}-04$ & $1.03 \mathrm{E}-06$ & $9.71 \mathrm{E}-07$ & $1.65 \mathrm{E}-08$ & $4.10 \mathrm{E}-04$ & $1.74 \mathrm{E}-07$ & $1.52 \mathrm{E}-07$ & $9.83 \mathrm{E}-09$ \\
\hline Th227 & $3.40 \mathrm{E}-02$ & $1.57 \mathrm{E}-04$ & $1.31 \mathrm{E}-04$ & $1.14 \mathrm{E}-05$ & $3.41 \mathrm{E}-02$ & $5.33 \mathrm{E}-05$ & $3.75 \mathrm{E}-05$ & $8.17 \mathrm{E}-06$ \\
\hline $\mathrm{Ra} 223$ & $3.28 \mathrm{E}-02$ & $1.64 \mathrm{E}-04$ & $1.28 \mathrm{E}-04$ & $1.35 \mathrm{E}-05$ & $3.28 \mathrm{E}-02$ & $6.33 \mathrm{E}-05$ & $4.46 \mathrm{E}-05$ & $9.25 \mathrm{E}-06$ \\
\hline Rn219 & $3.88 \mathrm{E}-02$ & $1.81 \mathrm{E}-04$ & $1.65 \mathrm{E}-04$ & $6.46 \mathrm{E}-06$ & $3.89 \mathrm{E}-02$ & $3.64 \mathrm{E}-05$ & $2.70 \mathrm{E}-05$ & $4.75 \mathrm{E}-06$ \\
\hline Po215 & $4.25 \mathrm{E}-02$ & $2.00 \mathrm{E}-04$ & $1.96 \mathrm{E}-04$ & $2.18 \mathrm{E}-07$ & $4.25 \mathrm{E}-02$ & $1.89 \mathrm{E}-05$ & $1.90 \mathrm{E}-05$ & $2.15 \mathrm{E}-08$ \\
\hline $\mathrm{Pb} 211$ & $6.71 \mathrm{E}-04$ & $1.33 \mathrm{E}-04$ & $1.16 \mathrm{E}-04$ & $1.07 \mathrm{E}-05$ & 7.67E-04 & $3.86 \mathrm{E}-05$ & $2.39 \mathrm{E}-05$ & $5.38 \mathrm{E}-06$ \\
\hline $\mathrm{Bi} 211$ & $3.76 \mathrm{E}-02$ & $1.65 \mathrm{E}-04$ & $1.52 \mathrm{E}-04$ & $5.58 \mathrm{E}-06$ & $3.78 \mathrm{E}-02$ & $3.20 \mathrm{E}-05$ & $2.36 \mathrm{E}-05$ & $4.10 \mathrm{E}-06$ \\
\hline T1207 & 7.33E-04 & $1.25 \mathrm{E}-04$ & $1.20 \mathrm{E}-04$ & $3.80 \mathrm{E}-06$ & $8.42 \mathrm{E}-04$ & $1.29 \mathrm{E}-05$ & $1.23 \mathrm{E}-05$ & $1.80 \mathrm{E}-07$ \\
\hline
\end{tabular}

*multiplied by 2 for exposure in sediment (2П exposure instead of $\Pi$ exposure) 